\title{
The Making of the Myth in Postcolonial Development: Material-Conceptual Landscape Transformation in Sixteenth-Century Veracruz
}

\author{
Andrew Sluyter \\ Department of Geography, The Pennsylvania State University
}

\begin{abstract}
European colonialism entailed material and conceptual landscape transformations that continue to define the parameters for postcolonial development. The major conceptual landscape transformation, termed the "pristine myth" for the Americas, remains a cultural foundation for the binary categorization of the world into a rationally progressive West versus an irrationally traditional non-West, thus driving the social and environmental contradictions of postcolonial development efforts. Despite much evidence that contradicts the pristine myth-the myth in postcolonial development - it retains a pernicious grip on the Western popular imagination because attempts to falsify it have not demonstrated its emergence through a colonial process that materially and conceptually transformed landscapes while simultaneously obscuring such transformation. Study of sixteenth-century landscape transformation in the environs of the port of Veracruz demonstrates the significance of a material-conceptual, positive-feedback process in the emergence of a myth of increasingly rational land-use over the course of the colonial and postcolonial periods, when, in fact, the opposite transformation has occurred. That landscape served as the beachhead for the Spanish colonization of North America and thus influenced the initial conceptualization of New Spain, as well as undergoing some of the earliest material transformations due to disease and livestock introductions. Although this occurred early in the process of global colonization, a detailed database of land-grant documents enables reconstruction of interactions among population, vegetation, livestock, and categories of land use, cover, and tenure. Identification of such key variables in a positive-feedback process that simultaneously transformed landscape and obscured that transformation tentatively provides the basis for a more general falsification of the myth in postcolonial development. Key Words: the Americas, colonialism, development theory, environmental and cultural sustainability, landscape ecology, landscape transformation, Mexico, nature, Veracruz, wilderness.
\end{abstract}

I have a feeling myths are a bit like malaria. Malaria appears as a headache, a stomachache; it festers and spreads. Which is more or less what myths do. They die hard (Miguel Ángel Asturias ${ }^{1}$ ).

$\mathrm{H}$

ernando Cortés, writing his first dispatch to Charles $\mathrm{V}$ a few months after landing at Chalchicueyecan in 1519, described the tropical lowland environs of his beachhead as "beautiful bottomlands and river banks" and, with a possessive eye, judged them to be "very apt and agreeable for traveling through and for pasturing all kinds of livestock" (Cortés 1988:20).2
Within half a century of establishing that initial beachhead on the mainland and going on to colonize much of the Americas, the Spaniards had transformed the landscape to match Cortés's prospectus for colonization, so much so that by 1580 the chief magistrate of Veracruz could report the region inland from the port as "so fertile and full of pastures that more than 150,000 head of livestock, between the cows and the mares, ordinarily graze within little more than seven leagues all around, even without counting the innumerable sheep that descend from the highlands to over-winter" 
(JGI, ms. xxv-8, f. 5) ${ }^{3}$. In the interim, Chalchicueyecan had become San Juan de Ulúa, the deep-water anchorage for the river port of Veracruz, the designated destination of the Seville fleet, and the entrepôt for the colony of New Spain. Smallpox and typhus epidemics had reduced the native population of some half a million by ninety percent, and vast herds and flocks grazed amid the deserted villages (Simpson 1952; Sluyter 1996, 1997a, 1998). Yet by the mid-nineteenth century, in the first comprehensive description of the region's vegetation, Carl Christian Sartorius (1961:9) reported a "dreary wilderness, overgrown with low thorny mimosas," elaborating on a slightly earlier sketch by another German naturalist (von Humboldt 1966:vol. 4, 154-56) and contrasting with Cortés's description of three centuries prior.

Those three firsthand accounts-by a conquistador at the inception of the colonial project, by a bureaucrat of the established colony, and by an expatriate scientist-entrepreneur at the dawn of Mexico's postcolonial period - signpost a dramatic material transformation of the landscape. Its consequences have persisted even with the waning of the sovereign power of European states, as the legacies of colonial land-use practices, such as vegetation change, have defined the material parameters for postcolonial land-use options (Melville 1990). The three accounts also parallel a conceptual transformation, a landscape recategorization that emerged over the colonial period and that has recently been termed "the pristine myth" in relation to the Americas (Denevan 1992a; Whitmore and Turner 1992) and "the myth of emptiness" more generally (Blaut 1993:15). According to that erroneous categorization, precolonial landscapes lacked dense populations and productive land uses, and therefore native cultures lacked the rationality to use their lands effectively. That transformation's consequences have also persisted to define the conceptual parameters for postcolonial land-use options, to the degree that postcolonial development models continue to promote the often-detrimental diffusion of institutions and technologies from the West to the non-West, continue to define success according to Western measures, and continue to devalue non-Western alternatives to modernization. Understanding the conceptual transformation of the precolonial Americas into "the pristine New World," and thereby more effectively falsifying the myth in postcolonial development, thus remains essential to reconceptualizing non-
Western cultural ecologies as alternatives rather than precursors to Westernization.

Falsifying the pristine myth requires demonstration of its emergence as a myth during the colonial period and its persistence into the postcolonial period, through a process that materially and conceptually transformed landscapes while simultaneously obscuring that process. Prior studies of the emergence of the pristine myth have addressed both material (Denevan 1992a) and conceptual (Bowden 1992) landscape transformation, but without systematically investigating material-conceptual feedbacks, which seem to have been central to obscuring such transformation. Nonetheless, the complementary insights of those two research efforts do provide stimulus and direction for the present study of the sixteenth-century transformation of the environs of the port of Veracruz (Figure 1). They facilitate identification of a material-conceptual, positive feedback process in the emergence of a myth that land use was increasingly rational over the course of the colonial and postcolonial periods, when, in fact, the opposite was happening. As the beachhead for the Spanish colonization of North America, that landscape thus influenced the initial conceptualization of New Spain while undergoing some of the earliest material transformations due to disease and livestock introductions. Although early in the process of global colonization, these events left a detailed database of land-grant documents that enables reconstruction of interactions among native population, vegetation, livestock, and categories of land use, cover, and tenure. Through the identification of such key variables in a positive feedback process that simultaneously transformed landscape and obscured that transformation, this study tentatively provides the basis for a more general falsification of the colonial myth in postcolonial development.

\section{Material-Conceptual Landscape Transformation and the Pristine Myth}

The firsthand accounts by Cortés, the chief magistrate, and Sartorius seem to sketch out the material transformation of the Veracruz landscape over the colonial period. As throughout the Americas, native depopulation due to epidemics and the introduction of exotic biota, technologies, and institutions seem to have transformed 


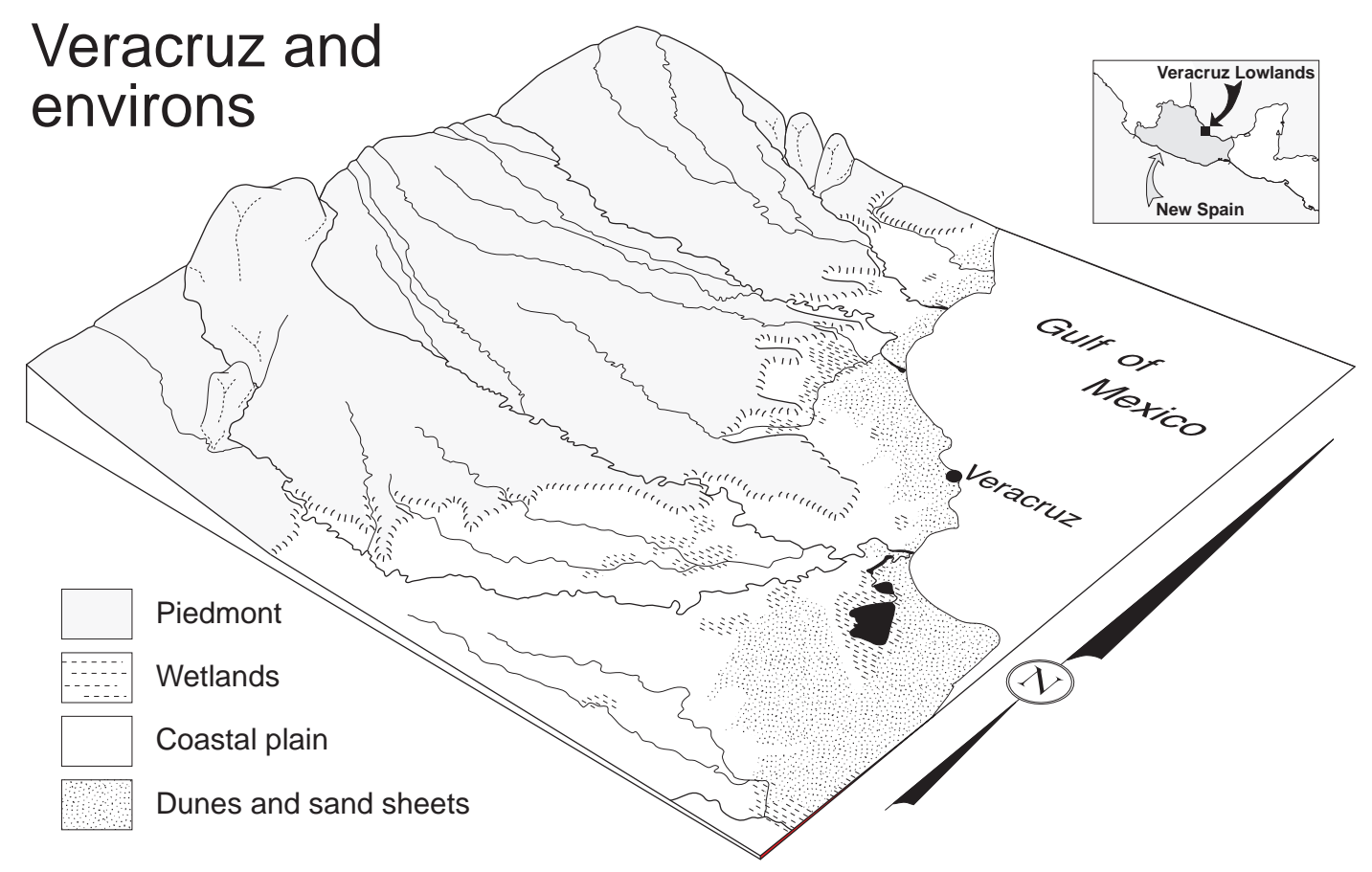

Figure 1. The port of Veracruz and environs: the belt of dunes fronting the Gulf of Mexico, the narrow coastal plain with its wetlands, and the piedmont dissected by the ravines of the streams draining the escarpment of the Sierra Madre Oriental to the west.

the landscape on a scale and to a degree comparable to the last Pleistocene deglaciation, when people first occupied the Americas (Crosby 1972). Even with the vast reduction of sovereign European power in the Americas during the nineteenth century, the inertia of those colonial transformations has continued to define the material parameters for postcolonial land-use options. In some cases, colonial degradation of particular resources-soil erosion due to overgrazing, for example-rather than a "naturally impoverished resource base" has contributed to postcolonial economic marginalization (Melville 1990). In other cases, colonization enhanced particular resources, as in the case of forest expansion into abandoned clearings with the destruction of native agriculture (Sauer 1966). For Veracruz, the above accounts imply an extreme degradation of the lowland vegetation due to colonial overgrazing.

The three accounts also seem to sketch a conceptual landscape transformation, the colonial recategorization of the Americas as a pristine wilderness. That "pristine myth" characterizes precolonial landscapes as sparsely populated and extensively used, "wilderness" in the "classic
European sense of uninhabited land" (Bowden 1992:6). Native cultures therefore lacked the rationality to effectively use their lands; and, as the binary complement to that conceptual transformation of the Americas, Europe became categorized as the source of rationality and enlightened innovation diffusing into the vacuum of the colonies. The colonial reconfiguration of the global distribution of resources, labor, and capital thus became naturalized and justified through a parallel redistribution of oppositional categories: cultivated versus wilderness, civilized versus savage, enlightened versus despotic, social versus natural, progressive versus traditional, developed versus developing, core versus periphery, innovative versus imitative, and other synonyms for, essentially, advanced versus retarded (Wolf 1982). To Europeans, after all, the category "New World" came to mean a region both newly brought within the European purview as well as a newer version of Europe, one with immature cultures and resources that, through improvement, eventually would become like Europe-colonization being the process through which the savagery of the New World would catch up to the civilization of the Old, through which the irrational, natural, 
and static would develop into the rational, social, and dynamic (O'Gorman 1958; Todorov 1984; Hulme 1992). Because such colonial categorizations were integral to the process of escalating material redistributions rather than derivative ideological props, they infused and became axiomatic to every expression of the Western worldview, from science to literature (Said 1979, 1993; Lowe 1991; Hulme 1992; Latour 1993).

Despite much empirical evidence that contradicts the myth in postcolonial development, whether termed the "pristine myth" or "the myth of emptiness," it retains its pernicious grip on the popular imagination in Western, and Westernized, culture (Turner and Butzer 1992; Blaut 1993). Postcolonial development models continue to promote the diffusion of institutions and technologies from the West to the non-West-as well as the economically profitable counter-flowrather than acknowledging that developed regions came into being through a global process of colonialism that cannot be repeated in the postcolonial present without radical redistributions of capital and levels of consumption (Wallerstein 1974; Brookfield 1975; Wolf 1982; Blaut 1987, 1993). World-system theorists' recategorization of regions as developed versus underdeveloped (as opposed to developed versus developing) thus exposes an interdependent, unequal, and selfperpetuating economic relationship. But, at the same time, that theory's oppositional category of core versus periphery itself perpetuates the subsuming cultural relationship that devalues nonWestern alternatives to modernization, even though those alternatives might potentially be more sustainable because they are rooted in knowledge of the dynamic realities of particular cultures and environments (Sauer 1956; Altieri 1987; Wilken 1987; Clay 1988; Browder 1989; Hecht and Cockburn 1989; Gliessman 1990; Netting 1993; Yapa 1993; Jackson 1994). Continued pleas by some public-land managers for recognition of the continuing consequences of precolonial land use demonstrate the pristine myth's influence on land-use policy in North America, whether oriented towards the preservation of "wilderness" or the development of "natural" resources (MacCleery 1994; Willems-Braun 1997; Peacock 1998; Sluyter et al. 1998). Research in West Africa on the influence of a colonial pristine myth on postcolonial development confirms the persistence of the more general myth of emptiness within governmental and non- governmental organizations (Fairhead and Leach 1995). The pristine myth, initiated during European colonization and in all of its many expressions (Lowe 1991), thus remains a cultural foundation for the binary categorization of the world into a rationally progressive West versus an irrationally traditional non-West.

The pristine myth seems to persist so powerfully because persistence is intrinsic to it. As a foundational category in the conceptualization of the West as the opposite of and rationally superior to the non-West, the pristine myth is integral to Western culture qua "Western." The same ineluctability, of course, pertains to all cultures' foundational categories, those binary oppositions that define any culture as different from all others, but the crucial difference between Western and non-Western categorizations is the spatial scale over which the former have come to have such an impact and, therefore, their power (Latour 1993). Diffusion also, of course, remains highly profitable for the diffusor. Compared to the cultural and economic inertia of the pristine myth, then, any isolated data that might potentially falsify it tend to become relatively insignificant-dismissable as "an exception that proves the rule." While syntheses of data for entire continents (Denevan 1992a, 1992b; Doolittle 1992; Turner and Butzer 1992; Whitmore and Turner 1992; Sluyter 1994) should prove more effective at falsifying the pristine myth than individual case studies, all such reconstructions, being based on proxy data rather than direct observations, remain inescapably inferential and as prone to controversy as the many estimates for the ca. 1492 population of the Americas (Henige 1998).

Any attempt to prove the pristine myth falsemust therefore show its emergence as a myth during the colonial period by demonstrating both the material and the conceptual landscape transformations involved, as well as identifying a transformative process that served to conceal such transformations. In other words, effective falsification requires us to recognize just how culturally integrated the pristine myth remains, while at the same time falsifying all three of its mutually supporting claims: (a) that Westernization has materially transformed pristine precolonial landscapes into productive landscapes; (b) that Westernization has not conceptually transformed nonpristine precolonial landscapes into pristine precolonial landscapes; (c) that the pristine myth 
is not a myth because landscapes, unlike chromosomes and quasars, are open to universal scrutiny and cannot conceal truth. In contrast, most existing studies that attempt to falsify the pristine myth have focused on demonstrating material landscape transformations that have obscured dense native populations and productive land uses (Denevan 1992a). Many fewer studies have considered the conceptual transformation of nonpristine precolonial landscapes into "the pristine New World" (Bowden 1992). Yet while neither research effort has systematically investigated how material-conceptual feedback mechanisms might have endowed the myth with such a powerful cultural inertia, they do yield complementary insights that stimulate just such an effort.

Much of the effort to understand material transformation of the precolonial and colonial landscapes of the Americas, and thereby to falsify the pristine myth, derives from C. O. Sauer (Denevan 1996; Parsons 1996). In the 1930s, with a then controversially high estimate of half a million people for northwestern Mexico alone, he initiated a research tradition that now places the precolonial population of the Americas at more than fifty million, reduced to about five million by 1650 (Sauer 1935; Denevan 1992b). Relict agricultural fields and cultural vegetation over broad regions confirm that precolonial landscapes were densely inhabited and much modified (White 1984; Denevan 1992a). Without such research on material landscape transformations, the furor over representations of competing land-use options remains incapable of informing either institutional policies or individual habits of thought and practice (Sluyter 1997b). In fact, continuing controversy among scholars regarding many aspects of the precolonial and colonial Americas-from native populations and their declines (Harris 1994; Henige 1998), to the extents of intensive agricultural systems (Pohl et al. 1996; Deur 1997), to the impacts of native burning on forests (Peacock 1998) - confirms the need for much more such research before a scholarly consensus emerges. Moreover, going well beyond such debates among academics, rational consideration of the potential of alternative land-use models requires more precise data on precolonial and colonial land uses. For example, better understanding of the extent and character of precolonial burning in the northeastern U.S. remains essential to addressing the ongoing and widespread replacement of oak by late successional taxa, possibly related to the twentieth-century diffusion of European forestmanagement practices such as fire suppression (Sluyter et al. 1998).

Much of the effort to understand conceptual transformation of American landscapes derives from J. K. Wright (Lowenthal and Bowden 1976). As he proposed more than fifty years ago, "historical geosophy" or the study of changes in knowledge about places "can show us where the ways we observe and think fit into a larger scheme. By helping us better to understand the relations of scientific geography to the historical and cultural conditions of which it is a product, it can enable us to become better-rounded scientific geographers" (Wright 1947:12). At the most general level, critics of modern culture and agriculture have summed up the making of the pristine myth: Europeans colonized the Americas with vision to the exclusion of sight, with visions of former places but without the sight to see the environments and cultures they were colonizing (Berry 1996; Jackson 1994). More systematic study, particularly the most comprehensive study of the emergence of the pristine myth in the U.S. by a historical geosopher, emphasizes deliberate myth making (Bowden 1992). Seemingly, a colonial elite initially imposed an ideology of environmental and cultural primitivism, characterizing the land as predeveloped and the natives as preagricultural, in order to facilitate the accumulation of territory. A subsequent, postcolonial elite somewhat modified that myth to support nationalism: the heroic conversion of primordial nature, including its noble savages, into an egalitarian nation of rugged individualists marked a homegrown progression through the stages of social evolution so perfect as to be exceptional, a Midas culture that had gone from the blank page of pristine nature to civilization in two centuries flat and that had thus become not only a part of the West but, arguably, the best of the West. Little wonder that postcolonial elites in Latin America aspired to become "Yankees of the south."

Yet even while one appreciates the role of elites in fabricating ideology, feedbacks between conceptual and material landscape transformations also seem essential to the emergence of the pristine myth, despite having gone largely unstudied. After all, the complex interactions of the varieties of colonialist and nationalist rhetorics-from politics and religion to art and science, each drawing on a diverse mix of antecedents (Glacken 1967; Lowenthal 1976; Schama 
1995) — could hardly have comprised a seamless ideological conspiracy. Moreover, as Cronon (1983) and Denevan (1992a) suggest, material transformations would have fed back into conceptual transformations; by the time nationalists were modifying the colonial version of the pristine myth, native depopulation and consequent forest invasion of former agricultural and hunting lands would have materially validated conceptual categories such as "forest primeval." Material landscape transformation would thus have acted as a "visual vehicle of subtle and gradual inculcation ... to make what is patently cultural appear as if it were natural" (Duncan 1990:19). In other words, as cultural geographers have demonstrated in other contexts (Cosgrove 1993; Mitchell 1996) by employing a similar analytic framework as landscape ecologists (Zimmerer 1994; Pickett and Cadenasso 1995), landscape patterning is both a result of transformation and a parameter for further transformation through material and conceptual processes such as human labor and categorization, with landscape patterning influencing both the habits of thought and practice that lend regularity to such processes and the conflicts that disturb that regularity.

Sauer's (1966) insight into the relationship between native depopulation and forest invasion of cultural savannas in the Caribbean most directly suggests a possible feedback loop connecting material and conceptual landscape transformations in Veracruz. Initiated with Cortés's invention of the prospectus for the colonization of New Spain, that transformation revolved around native depopulation, livestock invasion, and vegetation change. Interactions among population, vegetation, livestock, and categories of land use, cover, and tenure therefore focus the following analysis of the Veracruz lowlands in the initial century of colonization.

\section{The Veracruz Lowlands}

By the end of the sixteenth century, Cortés's 1519 vision of a pastoral landscape was the reality, the Veracruz lowlands having become the quintessential cattle range of New Spain and winter pasture for transhumant flocks from the highlands (Sluyter 1998). Yet by the nineteenth century, according to von Humboldt and Sartorius, much of the region's grassland had become overgrown with thickets of thorny, deciduous shrubs and low trees. A belt of woodlands-fragmented by wetlands harboring mosquitoes, vectors for the yellow fever that gave Veracruz its macabre reputation (Arreola 1980; Siemens 1990a)—hugged the coast just inland of a jumble of sand dunes. But the traveler bound for Mexico City from the port quickly confronted the long climb through the "dreary wilderness" of the savanna country (Figure 2). The only respite before reaching the more temperate elevations of the Sierra Madre Oriental came when the road dipped into verdant river gorges. In general, except for the port itself, the lowlands remained the domain of vast herds of cattle through the colonial and into the early postcolonial periods, but sparsely populated and little cultivated (Skerritt Gardner 1989; Siemens 1990a; Sluyter 1996). Only with the fall of Porfirio Díaz and the ensuing land reform of the twentieth century did the reign of the cattle barons wane and rural population begin to rise appreciably from its colonial nadir. Mestizo immigrants from the highlands claimed ejido lands, expropriated from the haciendas and held communally. The state coffers funded the irrigation canals that allowed ejido sugar cane to challenge hacienda cattle, drawing the lowlands ever more tightly into the net of the global economy. While the irrigation and drainage projects of the twentieth century have obliterated much of the landscape Sartorius once rode through, especially on the coastal plain, his savanna "overgrown with low thorny mimosas" still dominates the piedmont.

More precisely defining that landscape transformation and the processes involved, even in material terms alone, quickly leads one into figurative and literal thickets. As one extreme in a range of possibility, the thickets of thorny shrubs and trees might well be the result of several centuries of overgrazing and degradation of the "beautiful bottomlands and river banks ... very apt and agreeable for traveling through and for pasturing all kinds of livestock" that Cortés reported in 1519. While Cortés, in an effort to gain Crown support for his project, might well have exaggerated the extent of such appealing conditions by extrapolating from the verdant environs of major riverine settlements such as Zempoala, a 1529 description suggests otherwise: "there are ten or twenty leagues of plain as flat as a floorboard, and in some places forty to eighty leagues, with grass as high as your knee or higher" (Lockhart and Otte 1976:195-196). Moreover, only fifty years after the introduction of cattle, a Veracruz priest emphasized the need to burn pastures every second Christmas to keep them palatable 


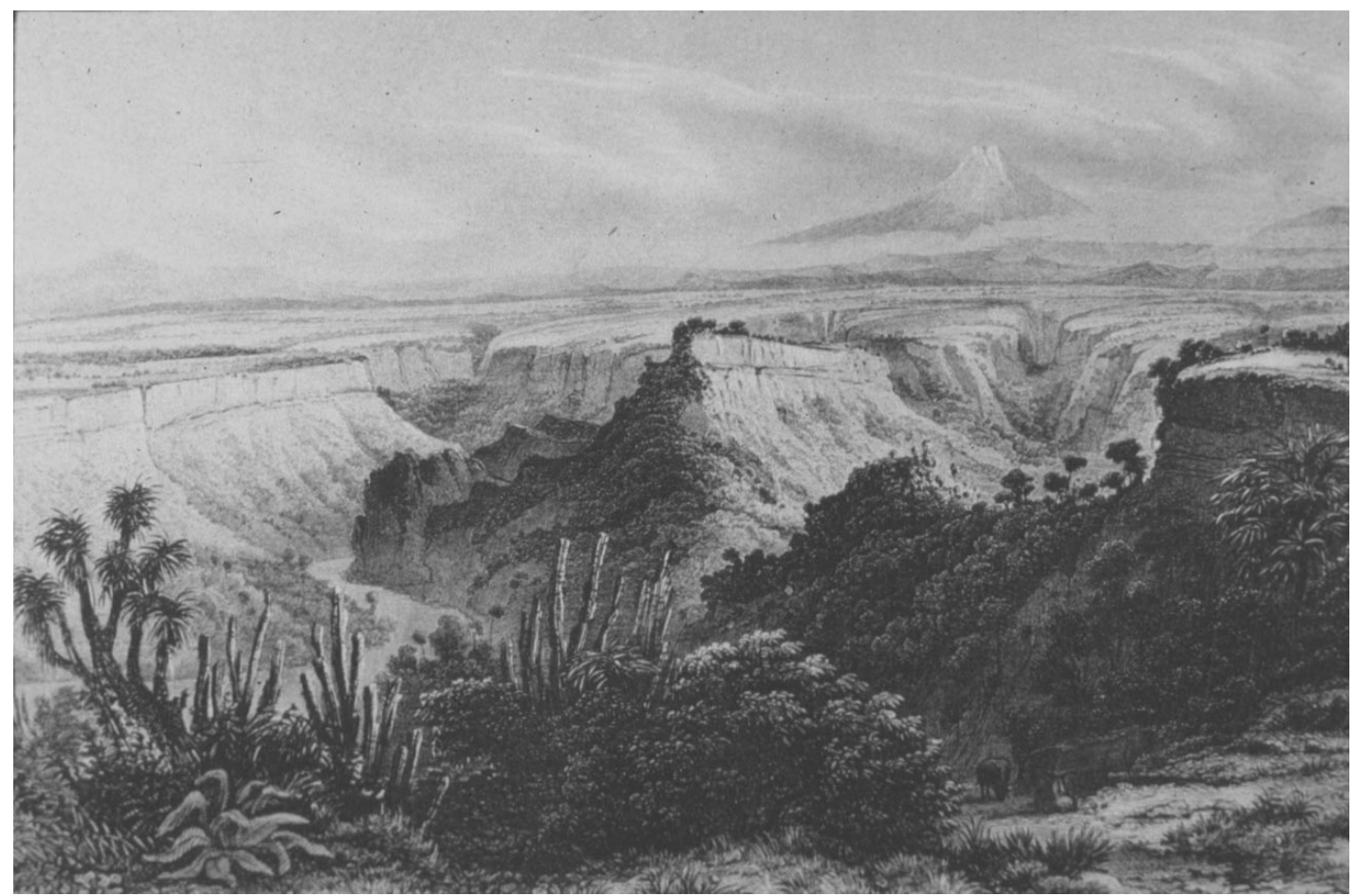

Figure 2. A representation of the view westward across the savanna country of the piedmont toward the escarpment of the Sierra Madre Oriental. Note the cows, cacti, and savanna characterized by thickets of shrubs and low trees. Original representation sketched around 1833 by Johann Moritz Rugendas; engraving from Mexico about 1850 (Sartorius 1961: plate opposite p. 40), originally published in 1859.

(Paso y Troncoso 1905: vol. 5, 201). Within another several decades, Bishop Mota y Escobar (1939- 1940:218) despaired at how the fields of Zempoala had been "converted into cattle estancias ..., all laid waste and ruined by a lot of thorny woods and sacas [coarse grasses or, possibly, cacti] due to the livestock." The long-standing thesis and substantial evidence that "hoofed locusts" can degrade vegetation also supports that possibility (Muir 1894:frontispiece; Simpson 1952; Crosby 1972; Melville 1994).

At the opposite extreme of the range of possibility, the seemingly degraded savanna vegetation Sartorius noted for the piedmont in the nineteenth century might already have existed when the Spaniards arrived - the result of native land use, of climate, or of both. After all, the effusive description by Cortés is tantalizingly brief and locationally ambiguous, and it rests on a minimum of experience with the native vegetation and a maximum of colonial boosterism. Besides, Cortés hailed from Estremadura and thus took one of the dustiest corners of Spain as his environmental benchmark. Equally, Mota y Escobar bemoaned the ruin of the vegetation in a single place on a long itinerary of ecclesiastical inspection, which suggests that the degradation on that particular hacienda might have been just as singular. More tellingly, pieced-together estimates of native population reveal that a dense agricultural population occupied these lowlands in 1519 (JGI, ms. xxv-8, ff. 5v-6r; Paso y Troncoso 1905:vol. 5, 201; Aguilar 1938:39; Las Casas 1951:vol. 3, 251; Martir de Angleria 1964:vol. 1, 421-27; Las Casas 1967:vol. 1, 261; Torquemada 1969:vol. 1, 251; Sluyter 1996). In the north, some 100,000 Totonac lived at Zempoala. Half that many inhabited nearby Ixcalpan, a place soon renamed Rinconada by the Spaniards. In the south, the Aztecs had garrisons at Cotaxtla and Cuauhtochco- - the former with a population of some 2,500, while the latter, across the river from its colonial reincarnation as Santiago Huatusco, was probably equally as large. In all, between the cities and the villages, the region's population seems to have exceeded 500,000 and produced a surplus, mainly cotton tribute for the Aztecs, in excess of subsistence. Relict earthen mounds, 
stone pyramids, agricultural terraces, and drainage ditches still litter the landscape and attest to the density of that agricultural occupance, at least to those who search for such faint spoor of ancient labor (García Payón 1971; Siemens 1983; Daneels 1992; Sluyter and Siemens 1992; Siemens 1998). Although the chronologies of many of those vestiges remain uncertain, the sediments of a small lake near Veracruz preserve a pollen record of maize agriculture several millennia long (Sluyter 1997c). Precolonial agriculturalists, long and densely settled on the land, would have had ample opportunity to modify the vegetation. Moreover, the current climate suggests that Sartorius's savannas and their thorny thickets of shrubs and trees might derive, at least in part, from the prolonged winter dry season. A mountain spur that reaches the coast at Punta Villa Rica blocks the winter northers and casts a rain shadow that falls deepest in the north of the region. The upper piedmont and the escarpment rising inland receive the greatest rainfall, the trade winds condensing as they sweep upslope. But the rainshadow parches the region from November through April, particularly in the north and on the lower piedmont. That seasonal aridity alone might account for a patchwork of low deciduous forest and, where vertisols inhibit tree growth, savannas, although how climate has changed in these lowlands over the last five hundred years remains unknown (García 1970; Gómez-Pompa 1973; Lauer 1978; INEGI 1981, 1984; Brown 1985). Such consideration of the roles of climate and precolonial land use has more generally begun to counter the prevailing thesis that ranching in New Spain invariably led to overgrazing and environmental degradation (Butzer 1992; Turner and Butzer 1992; O’Hara 1995; Sluyter 1997a, 1998).

Between those relatively simplistic possibilities lies a complexity about which we know approximately nothing, even focusing on material transformation of the vegetation, let alone beginning to integrate conceptual transformation and materialconceptual feedback. Nonetheless, Sauer's (1950, 1958) argument that many tropical savannas might be cultural rather than climatic or edaphic, at least in part a product of precolonial land use, suggests that the Veracruz landscape is not the result of any single factor per se, be it climate, overgrazing, or precolonial agriculture. Cortés's dispatch and the 1529 description of "ten or twenty leagues of plain ... with grass as high as your knee" thus might refer to a cultural savanna, the product of several millennia of native forest clearance, agriculture, and burning. With rapid native depopulation and old-field succession to shrubs and trees in the first few decades of colonization, as Sauer (1966) inferred had occurred in the Caribbean, the vegetation the livestock invaded when ranching boomed in the second half of the sixteenth century might already have been similar to the seemingly degraded vegetation that Sartorius described in the nineteenth century.

\section{Reconstructing Land-Grant and Vegetation Patterns ${ }^{4}$}

By making possible a reconstruction of the spatial and temporal dimensions of the livestock invasion in relation to vegetation and population change, the grants for the cattle and sheep estancias, or ranches, provide the best opportunity for a systematic evaluation of the roles of native land use, climate, and livestock in the region's landscape transformation (Figure 3; Sluyter 1997a, 1998). While Gregorio de Villalobos introduced the first calves in the 1520s, the viceroy began to grant estancias only after two decades of informal, small-scale ranching (Sluyter 1996). And, even with that opportunity to secure land tenure, the first land rush did not come until the 1560s, when the mining boom and consequent increase in Spanish immigration prompted a flood of grants that stretched the length of the narrow coastal plain, although some of those grants might have formalized estancias that had been in existence for a decade or more (Figure 4). Another land rush in the 1580s - as the native population throughout New Spain approached its nadir after the epidemics of the previous decade, resulting in reduced food supplies, high prices, and land grabbing-focused on the southern piedmont. In part, that second flurry of granting reflected speculation over the new royal highway linking Veracruz to Mexico City through Cotaxtla; estancias along the new official transport route would have good access to the domestic market for meat, wool, and tallow and to the export market for hides (Driever 1995). The continuing growth of the textile industry and consequent need for lowland winter pasture prompted the sheep grants of the turn of the century. The effective cessation of granting by 1619 paralleled the decline in silver production and modest population growth of the colony's second century. Besides, the landscape was full. By early in the seventeenth century, livestock grazed more than half of the lowlands inland from 


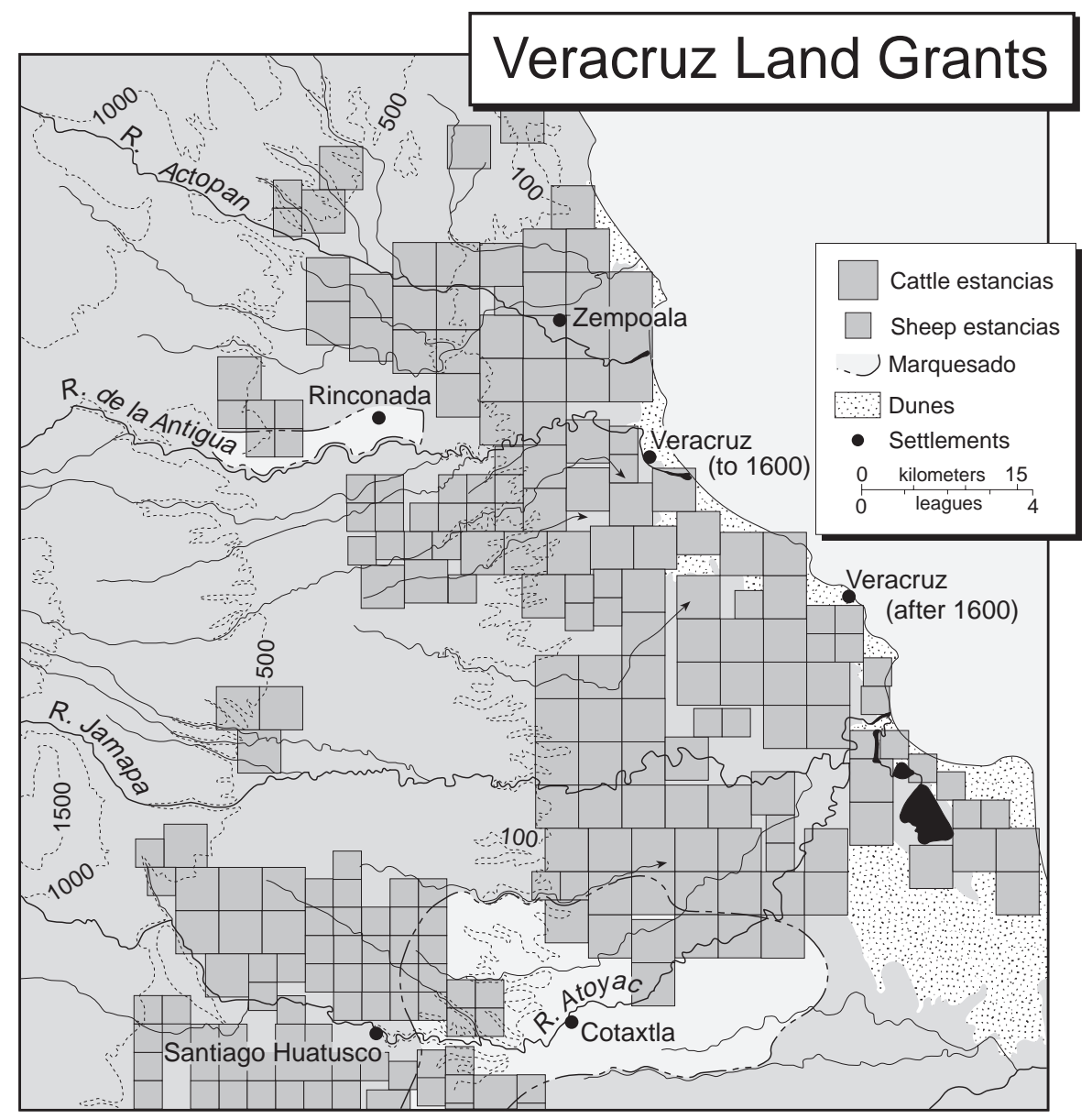

Figure 3. The grants for cattle and sheep ranches, settlements, and enclaves of the Marquesado del Valle.

Veracruz: 117 cattle estancias, a league on a side; 115 sheep estancias, two thirds of a league on a side. The cattle and sheep together probably numbered some 300,000 head, possibly an astounding five times that many (Sluyter 1998). Only the central piedmont, the Cotaxtla and Rinconada enclaves of the Marquesado del Valle, and buffers around new Spanish and surviving native communities remained ungranted. The central piedmont remained relatively inaccessible, dissected by deep ravines and far from the royal highways passing through Rinconada and Cotaxtla. Additional livestock probably occupied the Marquesado enclaves, where Corts and his heirs granted grazing leases, but the pertinent records remain scattered.

Beyond reconstructing the spatial and temporal dimensions of the livestock invasion, the same documents permit a systematic evaluation of its relationship to native depopulation and vegeta- tion change. In an attempt to ensure that grants would not prejudice the interests of the Crown, other ranchers, or native communities, a Crown official would inspect the location of a prospective estancia and submit a report to the viceroyincluding a recommendation to award or not award the grant, almost invariably the former. Sometimes those reports include descriptions of terrain, vegetation, and settlement; sometimes they include maps with graphic and textual landscape representations. While only some of the inspection reports survive, most of the actual grants are extant (Sluyter 1997a) and include information the viceregal scribes copied from the reports. While those data do not compare in quality to the much later, more systematic land surveys of the U.S., so amenable to statistical analysis (Cowell 1995), mapping the vegetation references in the grants does yield a perspective on the vegetation of a particular place at the time of livestock 

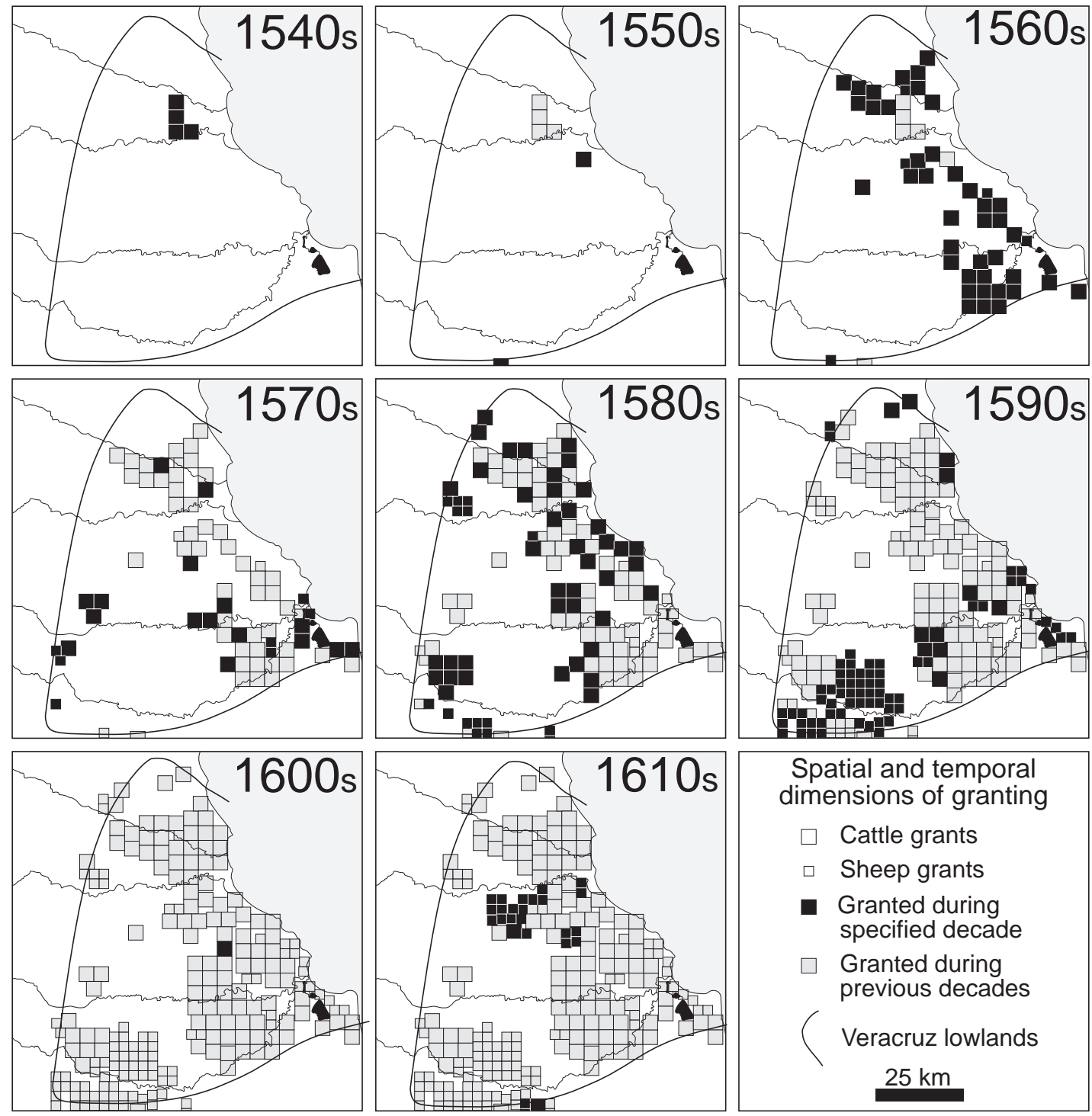

Spatial and temporal dimensions of granting

$\square$ Cattle grants

$\square$ Sheep grants

- Granted during specified decade

$\square$ Granted during previous decades

(Veracruz lowlands $25 \mathrm{~km}$

Figure 4. The spatial and temporal dimensions of granting, 1540s-1610s.

invasion (Figure 5). ${ }^{5}$ The coverage of the grants clearly must be biased in favor of areas supporting at least some grasslands, that resource being what prospective ranchers were after. Yet, despite that caveat, the grants do cover more than half of the region and, equally as critical, by definition, cover the lands that would have been most affected by the livestock invasion. Also, informal grazing might have affected the vegetation of a particular locale before a rancher obtained a grant to it, but the vegetation descriptions are contemporaneous with the major influx of livestock in any particular subregion and thus indicate the condition of the vegetation as each successive wave of the invasion engulfed a new ranching frontier. Prior livestock incursions would have been limited in number and therefore in impact.

\section{Material Landscape}

Transformation

The grants and attendant vegetation descriptions initially focused on the coastal plain, then shifted into the dunes and onto the piedmont. From hesitant beginnings in the north during the 


\section{Vegetation references}
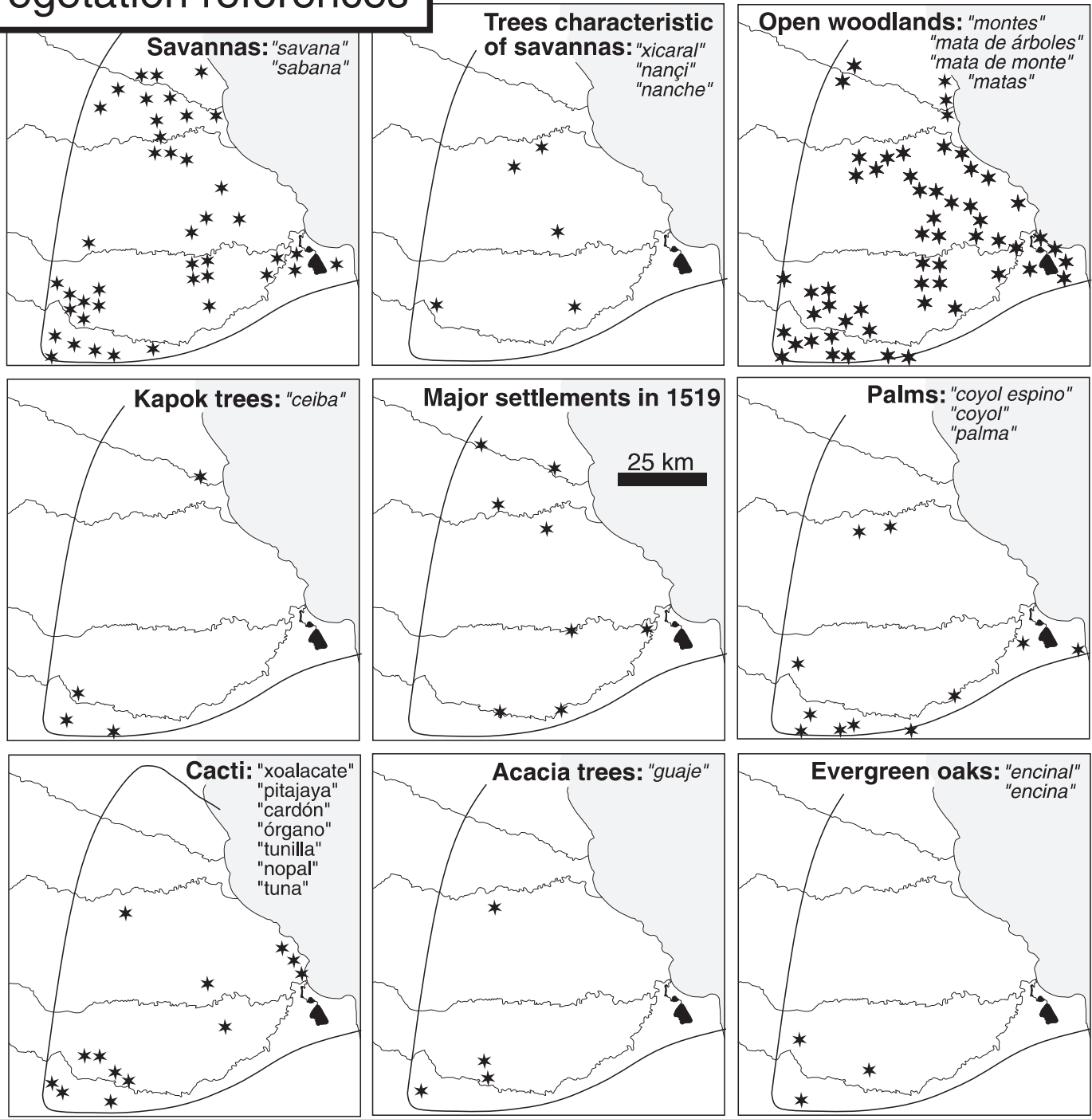

Figure 5. Vegetation references from the land grant documents and locations of major native settlements on the arrival of the Spaniards.

1540 s and 1550s, granting spread southward between the dunes and the piedmont during the 1560s. The vegetation references associated with the coastal plain, though brief, refer to savannas, matas, montes, and matas de monte-grasslands with scattered solitary trees and patches of open woodland or shrubland. The Hispanic terms monte and mata de monte, often abbreviated as mata, designate fragmented, open, degraded woodland or shrubland (Santamaría 1992; Corominas 1973; Rzedowski 1983). And, as one inspector put it in 1574, there was "nothing except montes and savanna" (AGN-T, vol. 32, exp. 4). The subsequent expansion into the dunes reveals a similarly open vegetation of grass and thickets. On the piedmont, the inspectors encountered stands of evergreen oaks at higher elevations but also the familiar savannas with matas de monte and mimosas, typically acacias (Acacia sp.). Throughout the region, as at present, evergreen trees fringed rivers and seasonal wetlands. Mangroves bordered the brackish 
lagoons among the dunes to the south of San Juan de Ulúa. And deciduous trees and shrubs dominated the woody vegetation elsewhere.

The land-grant documents thus echo Sartorius's nineteenth-century description as well as climatic and edaphic patterning, and therefore the sixteenth-century livestock invasion must have occupied the deciduous woodlands and thickets rather than creating them through degrading more open savanna. At the regional scale, then, the nineteenth-century vegetation and much present-day vegetation seem to derive from climatic and edaphic patterning (García 1970; INEGI 1981, 1984). The sand substrate of the dunes, despite receipt of more than $1,000 \mathrm{~mm}$ of precipitation, precludes even low deciduous forest except on the finer substrates of interdunal basins; shrubs and herbs therefore dominate much of the dune cordon. Similarly, the vertisols of the upper piedmont, despite receipt of more than 1,200 $\mathrm{mm}$ of precipitation, due to waterlogging during the wet season and deep cracking during the dry season, support a patchwork of savanna and low deciduous woodland, not surprisingly grading into shrubland on the drier, lower piedmont. Only the wetlands of the coastal plain can harbor extensive hydrophytic and evergreen communities. On the northern coastal plain, vertisols and the rainshadow suggest savanna with sparse tree growth as the precursor to the irrigated cane fields, although with gallery forests bordering streams and wetlands. To the south, increasing precipitation and phaeozems also suggest savanna, but with the possibility of extensive low deciduous woodland and shrubland as well as taller evergreens bordering streams and wetlands.

Scrutinizing more specific vegetation references - literally at the species level-the grants also reveal that precolonial land use had locally affected the vegetation that the Spaniards encountered. As the native population rapidly declined in the first two decades of colonization, from some 500,000 to less than 100,000 after the initial smallpox and measles epidemics, vegetation invaded former agricultural fields and communities. The grants record the palm trees that marked those fields. More specifically, the coyol palm (Acrocomia mexicana, Scheelea liebmannii) noted in the documents characteristically invades disturbed vegetation, especially when periodically burned (Pennington and Sarukhan 1968). ${ }^{6}$ Because the coyol bears edible fruit, the natives even encouraged its growth, the 1580 geographi- cal report classifying it as a "cultivated tree of this land" (JGI, xxv-8, f. 11r). In several cases, the grants clearly associate coyol palms with savannas near former native settlements (AGN-T, vol. 3331, exp. 1, ff. 1r-9r; AGN-M, vol. 33, ff. $112 \mathrm{v}-114 \mathrm{r}, 115 \mathrm{v}-116 \mathrm{v})$. One grant even notes "a savanna where there is a round mata that in the middle of it has a large clearing with two palms" (AGN-M, vol. 14, ff. 80v-81v) - a striking, but at the time seemingly unappreciated, description of thickets invading former agricultural fields.

If the coyol palm marked moribund agricultural fields, the ceiba marked the former settlements themselves. Natives protected the ceiba, the kapok or silk-cotton tree (Ceiba pentandra), its enormous canopy providing shade, its seed pods fiber, and its bark medicine (Niembro Rocas 1986; Mason and Mason 1987; Santamaría 1992). Sacred among the Maya as the World Tree, towering ceibas still grace the plazas of towns throughout the lowlands. The grants note ceibas near Zempoala and Santiago Huatusco as well as more generally associated with the stone and earthen mounds, the so-called cúes, that marked former settlements (AGN-M. vol. 9, ff. 33r-33v; vol. 10 , ff. 45v-46r; vol. 14, ff. 161v-162v; vol. 15, ff. $25 \mathrm{v}-26 \mathrm{v}, 86 \mathrm{r}-87 \mathrm{r}$; vol. 17, ff. 25v-26v). Significantly, lone ceibas rose above thickets of low trees and shrubs: "in a savanna where there is a large mata, and in the middle of it a large ceiba rising above the trees of the said mata"; "a round mata and in it a very large ceiba" (AGN-M, vol. 15, f. 26r; vol. 17, ff. 25v-26r). The ceibas-and, more significantly, the matas de monte in which ceibas occurred-marked the overgrown settlements of the former native population, signposts to a moribund cultural landscape.

Yielding a more systematic view of landscape transformation than particularistic accounts such as those by Cortés and Mota y Escobar can ever provide, the land-grant documents reveal that the livestock invaded a cultural savannas, as opposed to a purely climatic or edaphic savanna. By the second half of the sixteenth century, these lowlands had become a matrix of savanna with patches of former settlement and agriculture undergoing rapid depopulation and old-field succession. Where the landscape had been most thoroughly disturbed, in agricultural fields and settlements, the thickets had invaded before the livestock. Livestock might well have influenced the floristic composition of the invading vegetation but seemingly not the structure - that is, the particular species involved but not the vegetation 
type. European weeds certainly followed the livestock and displaced native species. European clover, for example, had become so widespread in New Spain by 1555 that the Aztecs coined a new term: Castillan ocoxichitli, after the Castilian invaders and a native weed of similar appearance and ecology (Crosby 1986:152). But the struggle between grasslands and thickets would not have hinged so much on the particular flora involved as on the balance between disturbance by livestock versus disturbance by fire (Harris 1966; Cházaro Basáñez 1977; Anderson 1982). Heavy grazing would have tended to enhance the dispersal and fertilization of the mimosas as cattle browsed the leguminous pods and dispersed the seeds in their fertilizing cow flops while reducing the supply of fine fuel necessary to the frequent, low-intensity fires that suppress the seedlings of woody plants. Repeated, active burning of pastures would have consumed the woody species and favored the grasses. The documents only hint at such burning, a priest at Veracruz reporting that the pastures were "wont to be burned around Christmas time," for example, despite viceregal ordinances against such burning (Paso y Troncoso 1905:vol. 5, 194-95). But sedimentary charcoal confirms both precolonial and colonial burning in these lowlands (Siemens et al. 1988; Sluyter 1997c).

As the relatively minor role of cacti in the region's vegetation reveals, whatever the complex balance between grazing and burning in particular places and times, the livestock and cultural practices of the ranchers, at most, modulated the old-field succession toward "dreary wilderness, overgrown with low thorny mimosas." Cacti, sharply armed against even the most determined cow, provide the most certain diagnostic of overgrazing and vegetation degradation. As livestock assault the palatable plants, cacti displace them. Yet the grants reveal cacti as a relatively minor element of the landscape the livestock were invading, even as cacti remain generally unobtrusive at present, probably more related to the long dry season than to land-use history (Gómez-Pompa 1973).

While Spanish colonialism clearly did not materially transform a pristine, precolonial landscape into a productive landscape, the livestock invasion also did not have a major degradational impact on the vegetation. Rather, livestock seem to have refilled a vacated ecosystem niche. Before human occupance of the Veracruz lowlands, the vegetation had coevolved with Pleistocene her- bivores. Until the Holocene, such herbivores as glyptodonts and horses propagated many of the deciduous trees - such as the acacias and xicaros (Crescentia cujete) noted in some of the grants (Figure 5) - eating the pods and fruits, dispersing the seeds through digestive tracts, and fertilizing the seedlings with feces (Janzen and Martin 1982). ${ }^{7}$ With extinction of most of those herbivores, the palatable fruits containing indigestible seeds became an ecological anachronism. Evolved to propagate through extinct dispersal agents and increasingly assaulted by agricultural clearance and burning, the populations of xicaros and similar species must have become minor elements in the emerging cultural savanna. Only culturally valued trees, such as the coyol and ceiba, would have thrived. To some degree, then, native depopulation and livestock invasion reinstated the Pleistocene ecology and re-expanded the thorny thickets.

\section{Conceptual Landscape Transformation}

The Spaniards not only diffused epidemic diseases that materially depopulated and transformed the landscape, they implanted categories and other habits of thought that precipitated a conceptual transformation. In doing so, they largely ignored, remained oblivious to, and eventually eliminated many precolonial categories. Where natives had seen agricultural lands, Spaniards saw wasted lands and populated them with livestock. Cortés initially did so in rhetoric, and other Spaniards later did so in fact.

While the grant inspectors generally recognized the distinguishing cúes of moribund native settlements, the associated agricultural fields went unremarked. The Spaniards seem to have been unaware that natives had once excavated a labyrinth of ditches to manage the hydrology of the wetlands of the coastal plain, although the vestiges of more than two thousand ha of such ditches and intervening planting platforms remain discernible — at least, again, to those interested in such cultural spoor (Siemens 1983). Only one grant inspector even noticed those earthworks: "a small lake which appears in the rainy season . . . and marshes ditched straight southward" (AGN-M, vol. 15, ff. 191r-192r). Not a single inspector noted the even more extensive terraced agricultural fields of the lower piedmont (Sluyter and Siemens 1992). 
Instead, the Spaniards characterized prospective estancias as baldios or yermas - as wastelands or wild lands, as wilderness in the sense of empty, idle, unimproved land (AGN-M, vol. 8, ff. 190r190v; vol. 9, f. 91v; AGN-T, vol. 2702, exp. 12, ff. 386r-397v; vol. 2702, exp. 13, ff. 398r-406v; vol. 2764, exp. 15, ff. 181r-195v; vol. 2777, exp. 3, ff. 1r-9v; vol. 3331, exp. 1, ff. 1r-9r). That category not only underrepresented the extent of precolonial agricultural fields, many undergoing old-field succession due to depopulation, but circumvented viceregal legislation intended to protect the native communities that had survived, though much diminished, the epidemics of the early sixteenth century. Protecting natives, of course, also protected the revenue that the Crown derived through a head tax of one gold peso plus half a fanega of maize per tributario (Cook and Simpson 1948:11; Sanders 1992:8991). Despite that legislation (Recopilación 1987, libro 6, título 3, ley 20), which the grant inspections were intended to enforce, ranchers came into conflict with surviving native communities. In 1574, the viceroy granted Juan de Ocón and Isabel de Vergara two sheep estancias on the coastal plain, harbingers of the later land rush for lowland sheep pasture (AGN-T, vol. 32, exp. 4). The Núñez de Montalván brothers sued, claiming that the sheep grants conflicted with their own preexisting cattle estancias. For good measure, one Montalván brother claimed that Ocón and the grant inspector had conspired to coerce native acquiescence: "Juan de Ocón bribed the natives and made them drunk so that ... they would not protest" (AGN-T, vol. 32, exp. 4, without pagination). Equally pithy, and contradicting the original inspection report that had claimed that the natives themselves categorized the land under inspection as baldios, during the ensuing investigation, the natives testified that cattle had long posed a threat to their crops and livelihood: "there are some cattle estancias three or four leagues from this town that do great damage eating the crops and destroying the fruit trees." Despite that native resistance, the viceroy let the grants stand. Rather than the baldios, which were considered open range in Spain (Butzer 1988) and depicted in the original inspection report and the accompanying map (Figure 6), some of the lands being granted around the surviving native communities, in reality, were native orchards and agricultural fields. They might have been fallow at the time and thus overgrown and rather facilely categorized as matas de monte, but they remained part of the native subsistence systems nonetheless. Most of the native communities in the lowlands, weakened in part by such depredations, would not survive the Great Cocolixtle epidemic of the 1570s (Sluyter 1996).

Thus, in accumulating space, at least some Spaniards circumvented the legislation intended to protect native land tenure and thereby helped to make such legislation superfluous - on the books but with few native communities left to protect by the end of the first century of colonization. More significantly, in circumventing explicit laws, individuals were able to draw on the implicit, taken-for-granted environmental and spatial categories that formed the conceptual parameters for colonial space accumulation. Lands beyond the immediate confines of native communities equaled wasteland, a patchwork of seemingly unused grasslands and shrublands most rationally suited for grazing. Space equaled a map, the maps of the land grants at once recording space accumulation and land use as well as manifesting the conceptual parameters for the articulation of power through space in order to exert power over space: "cartography is part of the process by which territory becomes" (Harley 1992:532). The maps therefore did more than delineate the grid of Spanish space accumulation and record landscape patterns; like the categorical baldios in the texts of the land grants, cartographic representation was part of the transformative process resulting in those patterns.

Native cultures clearly also had cartographic traditions, but their modes of representation differed from those of Europeans and did not constitute a basis for immediate resistance. Native cartographies were rooted in the genesis of place, combining genealogical with spatial representations (Harley 1992). In that tradition too, maps inescapably manifested power as knowledge that constituted conceptual parameters for the articulation of power through space in order to control space. But the native tradition had more in common with Medieval cartography than the land-grant maps, the latter akin to other maps of the Renaissance and part of the emerging Cartesian representation of absolute, georeferenced space. Native communities eventually learned how to employ Spanish landscape representations in order to resist the appropriation of territory by the ranchers-but too little and too late, several generations after Cortés invented the colonial prospectus and just before the period of granting came to a close at the end of the colony's 


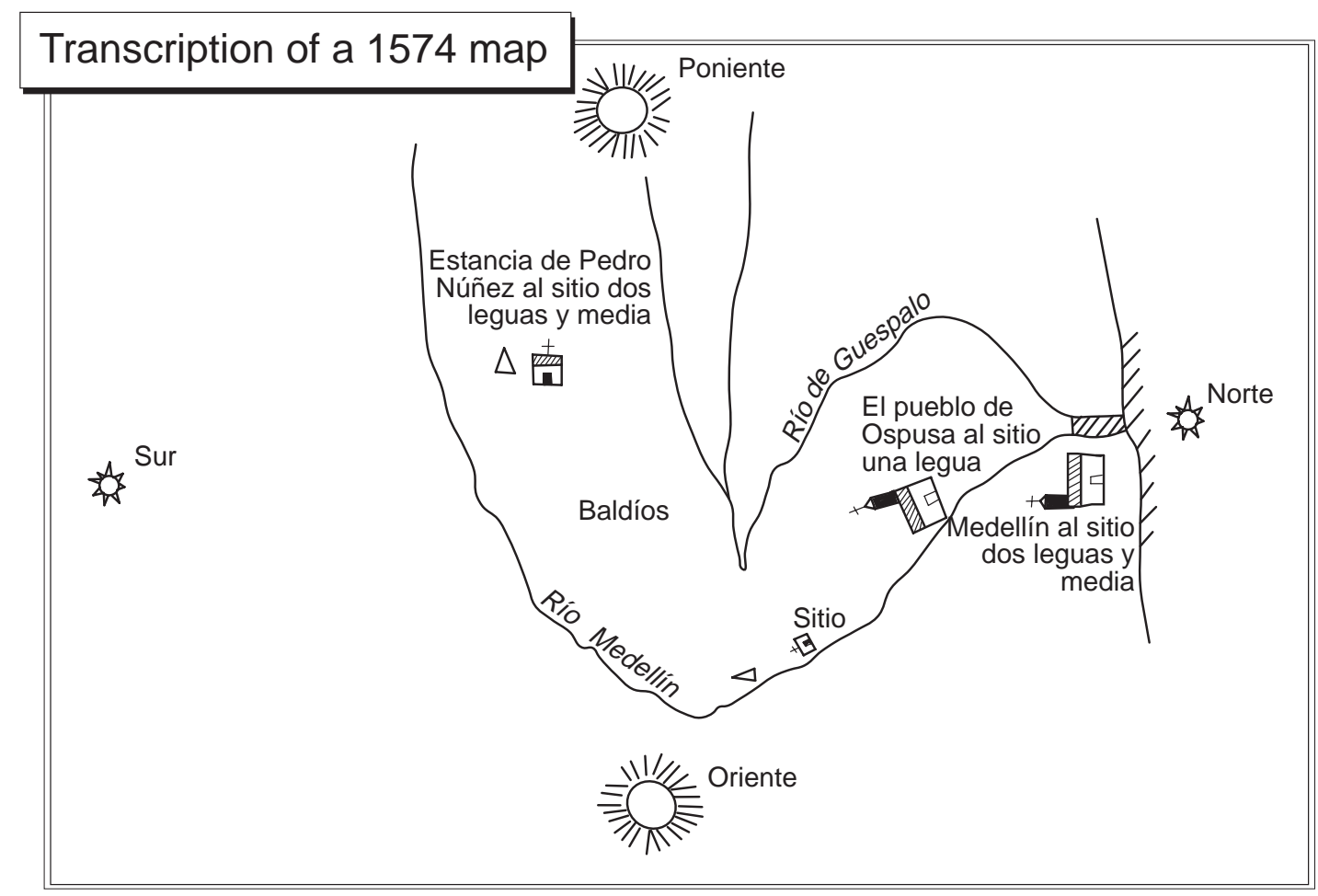

Figure 6. Transcription by author of a map from 1574 relating to a dispute over two sheep estancias (AGN-T: vol. 23, exp. 4 [ascension no. 556]).

first century. Only by 1590, in fact, did the natives of Santiago Huatusco finally request two sheep estancias (AGN-T, vol. 3331, exp. 1). In doing so, they employed the Spanish conceptualization of the landscape, both in categorizing the requested lands as baldios and in representing space as a map (Figure 7). Even so, although the map seems to include native representational elements, the local Crown official actually drafted it. Further upslope, where native communities had better weathered the epidemics - for as yet unknown reasons but perhaps related to a more dispersed settlement pattern-that process of effective resistance began somewhat earlier, by the 1560s, and continued through the turn of the century (AGN-M, vol. 7, ff. 217v, 219v-220r; vol. 8, ff. 194r-194v; vol. 11, f. 302r; vol. 14, ff. 359v-360v; AGN-T, vol. 2687, exp. 28-29; vol. 2688, exp. 6; vol. 2702, exp. 15; vol. 2723, exp. 10; vol. 2735, pt. 2, exp. 3; vol. 2742, exp. 14; vol. 2773, exp. 11; vol. 2776, exp. 5; vol. 2782, exp. 11; vol. 2809, exp. 6.).

Ultimately, the issue is not simply that a few Spaniards manipulated land-use categories to circumvent legislation intended to protect native communities. It is not simply that native commu- nities took time to learn those land-use categories in order to resist more effectively. Ultimately, the issue is that those Western categories became the taken-for-granted, be-all and end-all measures of productive land use. Understanding how they became and doggedly remain so through a materialconceptual feedback process is central to learning how to appreciate alternative landscapes.

\section{Material-Conceptual Positive Feedback}

To summarize the material and conceptual landscape transformations while rejoining them into a single material-conceptual analysis, systematic analysis of the land-grant documents demonstrates that the livestock invasion did not directly degrade the precolonial vegetation into the "dreary wilderness" that Sartorius reported in the nineteenth century. Nor had the interaction of precolonial land use, climate, and soils already produced such a landscape by 1519 . Instead, precolonial land use had created a matrix of cultural savanna with patches of settlement and 


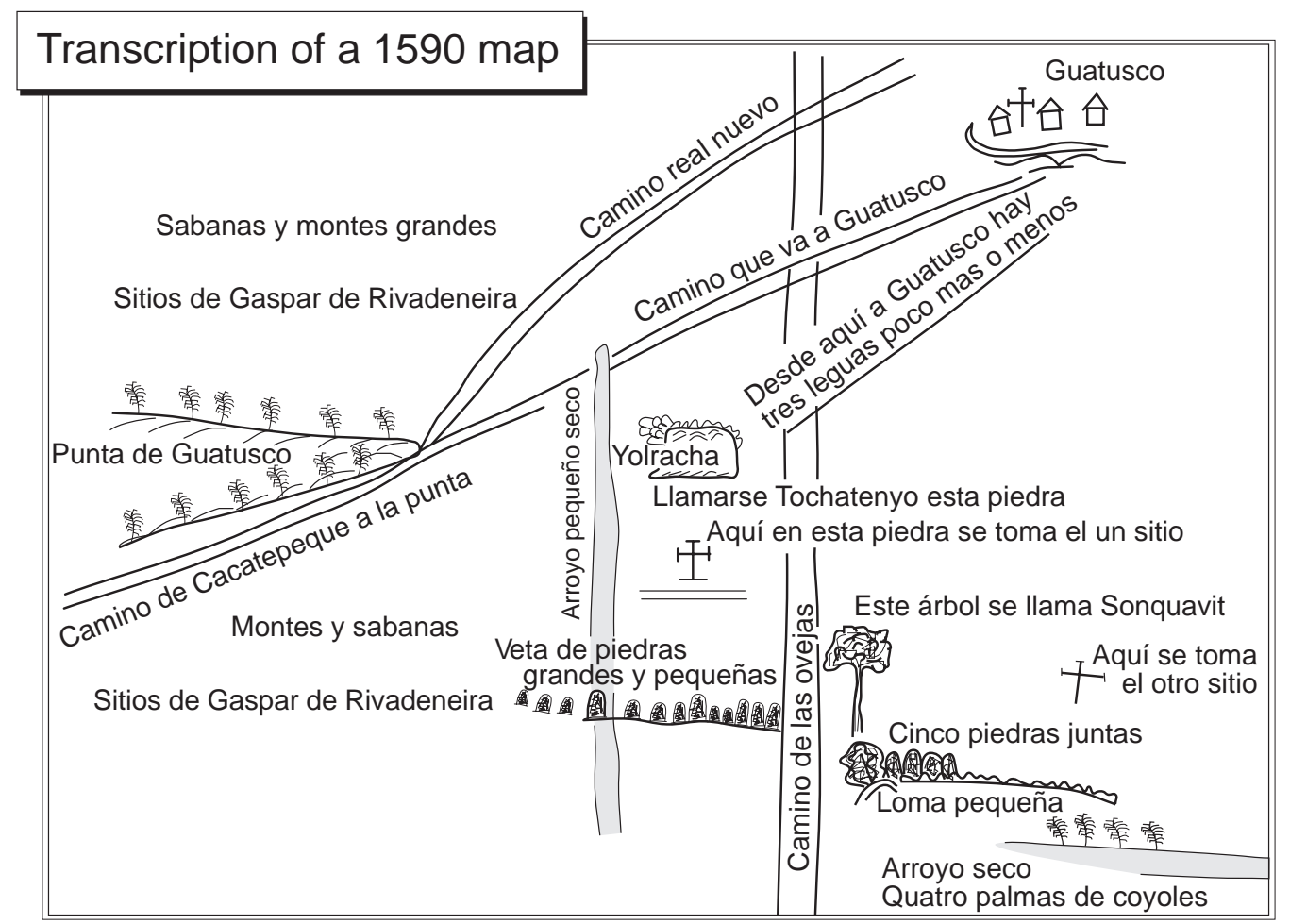

Figure 7. Transcription by author of a map from 1590 relating to a request for sheep estancias by the natives of Santiago Huatusco, rendered as "Guatusco" on the map (AGN-T: vol. 331, exp. 1, f. 9 [ascension no. 2358]).

agriculture. That material landscape patterning, together with landscape concepts diffused from Spain through the Antilles, constituted the parameters for Cortés's vision of a pastoral landscape. Depopulation due to epidemics of introduced smallpox and typhus created a moribund landscape, thickets invading former fields, cultural savannas, and settlements before the livestock. As the ranchers accumulated space and increasingly occupied the landscape with their herds and flocks after mid-century, they preempted the recovery of the surviving native population. By the turn of the century, livestock had almost entirely replaced people, thickets and pastures had replaced agriculture, and the colonial prospectus had become reality. Epidemiological and old-field successional processes thus resulted in a material landscape pattern that, together with the conceptual landscape pattern inherent in such categories as wasteland and ungranted space, constituted the parameters for further landscape transformation. The recategorization of moribund as well as surviving native fields and orchards as wasteland obscured the landscape modifications of native labor that would have hindered dispossession and made possible the recovery of native population and reversal of old-field succession. A positive feedback loop between material and conceptual processes, then, resulted in an inexorably unidirectional transformation into a depopulated landscape of livestock estancias. On the basis of that positive-feedback loop between depopulation and recategorization of agricultural land as wasteland, the conceptual parameters manifested in the land-grant documents and maps became selfratifying categories, materially precipitating the very landscape they erroneously described by visually validating their own conceptual parameters and erasing precolonial ones.

The lowlands of Veracruz consequently remained the near exclusive domain of vast cattle herds throughout the colonial period and into the early postcolonial period, the radical transformation of land use and meaning outlasting Spanish sovereign power. Only when ranchers burned the vegetation to reduce the thickets and promote grass did the newly postcolonial landscape hint at its precolonial morphology—seemingly, however, unnoticed by anyone except Sartorius: 
The reader must not picture to himself fair lovely meadows, but rather dreary wilderness, overgrown with low thorny mimosas, frequently varied with larger groups of trees and small forests ...; as far as the eye can reach, we see the umbellated spreading mimosas.... Nevertheless, this region has a peculiar charm for men of an enquiring turn. Traces of extinct tribes are here met with, of a dense agricultural population, who had been extirpated before the Spaniards invaded the country. When the tall grass is burnt down, we can see that the whole country was formed into terraces with the assistance of masonry. ... All is now concealed by trees or tall grass; for many miles scarcely a hut is built, where formerly every foot of land was as diligently cultivated as the banks of the Nile or the Euphrates in Solomon's time. We know not whether a plague or hunger, or warlike tribes from the North, or some great convulsion of nature destroyed the numerous population, indeed we have not the slightest clue, which would enable us to decide to what people these relics of great industrial activity belong (Sartorius 1961:9-10).

While Sartorius noted the vestiges of precolonial intensive agriculture that contradict the pristine myth, he interpreted them so as to support the categorization of the region as undeveloped and of its populace as irrational. To that German scientist and entrepreneur, imbued with the same cultural bias and liberal ideology of laissez-faire development as von Humboldt, those vestiges of a land use so different from the prevailing ranches suggested the fertility of the soils and thus the feasibility of coffee and sugar production-but only in concert with German immigration (von Mentz 1990:22-45). Thus he argued two contradictory positions: on the one hand, as demonstrated by the vestiges of precolonial land use, Veracruz had great potential for economic development through cultivation of tropical crops; on the other hand, Europeans rather than the natives or their mestizo descendants would have to bring about that modernization. In order to reconcile that logical contradiction, he ascribed the vestiges to "a dense agricultural population, who had been extirpated before the Spaniards invaded the country," a people that had cultivated "every foot of land . . . as diligently . . . as the banks of the Nile or the Euphrates in Solomon's time" (Sartorius 1961:10). In other words, he relegated the accomplishments of Native Americans to an antiquity unconnected with the indios and mestizos of postcolonial Mexico, whom he viewed as "undisturbed by any care for the future," as irrational, and therefore as incapable of rational land use without European, preferably German, guid- ance (Sartorius 1961:64-66, 83, passim). Thus he shared von Humboldt's cultural bias towards the native cultures of the Americas-both of them, as well as many other Westerners, asserting that any precolonial characteristics of the New World resembling those of the Old World must derive from Precolumbian diffusions.

When we consider that they had an almost exact knowledge of the duration of the year...., we are tempted to believe that this progress is not the effect of the intellectual development of the Americans themselves, but that they were indebted for it to their communication with some very cultivated nations of central Asia (von Humboldt 1811:vol. 1, 158-59).

An impartial consideration and observation of the Indians during many years forced me to the conclusion: that, according to their bodily organization, they are incapable of so high a degree of intellectual development as the Caucasian race. ... The religious systems of the Incas and Aztecs, their knowledge of astronomy, works of art, and mechanical labours for the purposes of every-day life, are the result of their powers of understanding, of the undeniable imitative talents of the whole race.... As yet we know not whether influences from the east may not have sown the first seeds of civilization (Sartorius 1961:64).

Sartorius's own modernization project failed, German emigrants favoring Texas and points north over Veracruz (Stevens 1967), but Mexicans from the highlands did colonize the lowlands around Veracruz in the twentieth century and began to farm lands expropriated from the cattle barons in the aftermath of the agrarian revolution. In a logical maneouver similar to Sartorius's, the nationalistic indigenist rhetoric, or indigenismo, reconciled retention of the pristine myth with glorification of the precolonial past by celebrating dead natives to the near exclusion of living ones, especially focusing on the Aztec military heroes and the long gone Classic Maya (Pozas and Pozas 1971; Zea 1975; Cockcroft 1990:147-48). In that categorization, although the intention of some intellectuals and artists might have been cultural relativism, the living natives and their land-use practices became categorically "traditional," too conservative to actively participate in economic development models that focused on the diffusion and adoption of Western institutions and technologies. The Maya became the "Greeks of the New World," the vestiges of precolonial agriculture beyond the pale of the touristic ruins continued to go largely unseen, and the measures of 
productivity and rationality continued to be naively Western.

Thus the concrete poured: state-engineered and -funded irrigation projects created the new sugar industry of the Veracruz lowlands, partially replacing the colonial landscape of extensive pastoral land use. Any knowledge that the ranches had themselves replaced a landscape of intensive agriculture, even while perpetuating some of the precolonial, cultural ecological complementary between wetlands and drylands (Sluyter 1994), lay beyond the terms of reference of the development planners. Just as ranching had presumably rationalized the precolonial landscape without considering the potential of precolonial models, industrialized production of agricultural commodities such as sugar became an intensification of land use and, ipso facto, a rational improvement over ranching - irrigating the dry, draining the wet, and ignoring the ecological potential of a seasonal complementarity between the two (Sluyter 1996). The engineers who came to develop the wetlands imposed a template intended to "mitigate" the putatively negative effects of flooding, but they failed to recognize-in fact, did not even seem able to articulate the possibilitythat such seasonal inundation had long been the basis of highly productive, local cultural ecologies. Their reports remain in the archive of the Secretariat of Hydraulic Resources and "give us many loaded words, flung as epithets: 'traditional' above all others, 'extensive' (which is almost as bad), and 'irrational,' or even 'vicious.' There is much 'disorder'; the plants and animals are mostly criollo, the grasses are only 'natural.' On every hand is subaprovechamiento, a failure to take full advantage" (Siemens 1998:213).

In both obscuring the intensive agriculture of the precolonial landscape and constituting an extensive land use, the desettlement and ranching of the colonial period, together with development concepts diffused from the West, thus became the parameters for the vision of postcolonial land-use planners and resulted in a landscape of industrial agriculture that further obscured the precolonial vestiges. Only recently has their morphology and function become reapparent (Siemens 1983; Sluyter and Siemens 1992). Attempts have followed to redeploy intensive wetland agriculture as a more sustainable alternative to draining wetlands and irrigating drylands, but such schemes have not been successful in part because of the diffusionist tendencies inherent to them, imposing yet another ready-made, exogenous solution on local contexts rather than fully shaking the colonial myth in postcolonial development (Chapin 1988). While the longevity of intensive wetland agriculture in some places, perhaps as long as three millennia in the Basin of Mexico and two in the Maya Lowlands, suggests its sustainability, the model of field form and function implemented in the Gulf Coast lowlands derives from the chinampas of the Basin of Mexico (Gómez-Pompa et al. 1982). The form and environmental context of the vestigial Veracruzan fields, however, suggests a much different function from the chinampas and therefore illustrates the inappropriateness of such diffusion. While the chinampas occur in lakes and necessitate precise control of water-level in order to function, the lowland fields occurred in backswamps and functioned in concert with seasonal fluctuations in water level (Sluyter 1994). Yet even while the chinampa model was being diffused to the lowlands, locals had been reinventing fields more appropriate to the backswamp context, initially motivated but subsequently discouraged by changes in Mexican economic policy (Siemens 1990b).

\section{Falsifying the Myth in Postcolonial Development}

Sauer, as an advisor to the Rockefeller Foundation during the 1940s, warned of the irrationality of ignoring the contextual knowledge of local farm families, but nonetheless the definition of progress for such international agencies and host governments has revolved around the industrialization, commodification, and homogenization of agriculture at the expense of dynamic local knowledge and biodiversity (Jennings 1988:50 56; Bebbington and Carney 1990; Zimmerer 1996). Because of the integrated reconfiguration of material and conceptual patterning at the global scale during the colonial period, the binary categorization of the world into developed core versus underdeveloped (or developing) periphery continues to remain a conceptual parameter for the postcolonial development project of Western, and Westernized, culture. That project drives the diffusion of institutions and technologies from the West to the non-West in an effort to rationalize land use at a global scale but tends to confound its own goals, hardly surprising given that a myth that emerged during the colonial period underlies 
the project's essential logic. Without a concerted effort to "unmake" that myth in postcolonial development, then, the hope embodied in the concept of "sustainable development" will remain an unrealizable contradiction in terms, an irrational figment of a Western vision that axiomatically privileges the very goals and practices that have precipitated the global environmental crises that led to that concept's emergence (Turner et al. 1990; Peet and Watts 1993; Wilbanks 1994). At the local scale of analysis, the negative consequences of Westernization have been less obvious as a general phenomenon, dismissable for any particular place as an "exception that proves the rule," as a transitional condition, or as an anomaly in the diffusion of modernization through "development space." Yet despite their ongoing destruction and their devaluation as being irrational or, at best, no more than "ethnoscientific," nonWestern alternatives to development are rooted in knowledge of the dynamic, complex realities of particular cultures and environments and might well be more sustainable than Westernization, whether they derive from the past or the present (Altieri 1987; Wilken 1987; Netting 1993; Jackson 1994).

Reconstruction of sixteenth-century landscape transformation in the Veracruz lowlands falsifies the myth in postcolonial development by analyzing landscape transformation as simultaneously material and conceptual. The analysis fulfills all three criteria for falsifying the pristine myth: (a) Westernization has not materially transformed a pristine precolonial landscape into a productive landscape; (b) Westernization has conceptually transformed a nonpristine precolonial landscape into a pristine precolonial landscape; and (c) the material-conceptual transformation of the Veracruz landscape, through a positive-feedback process between material and conceptual transformative processes, has itself concealed those processes despite the seemingly unambiguous nature of landscapes. The processes involved were as material as seeds dispersing according to genetically encoded mechanisms, as Crown officials drafting maps of land use, and as epidemics sweeping through populations lacking antibodies. The processes were as conceptual as laws controlling land tenure, as individuals speculating over the route of a new royal highway, and as grant inspectors categorizing landscape patches as unimproved. And the processes included a material-conceptual, positive feedback: the recategorization of old-field and fallow-field landscape patches as wasteland; consequent preemption of the recovery of native population; further old-field succession, and visual validation of a myth of progress from a pristine landscape towards an increasingly rational and productive landscape when, in fact, the opposite has occurred.

Nonetheless, the foregoing reconstruction remains a weak general falsification of the pristine myth for the Americas or, even more so, of the global myth of emptiness that underpins the logic of postcolonial development. No matter the significance of the Veracruz lowlands as the colonial beachhead for New Spain and thus for the continental initiation of what would become first a hemispheric and ultimately a global process of colonization, the foregoing remains particularistic. No matter the detail of the data relative to their sixteenth-century provenance, historical reconstruction inescapably remains partial and controversial, a characteristic of making inferences from proxy data as true for reconstructions of cultural phenomena as for reconstructions of environmental phenomena. Given the impossibility of making direct observations of paleoecological phenomena and given the cultural integration of the pristine myth, dismissal as an "exception that proves the rule" thus remains the probable fate of the Veracruz case.

Yet the reconstruction does identify key variables in an inexorable, positive-feedback process that simultaneously transformed landscape and obscured that transformation, thus providing the basis for a potential, more general "unmaking" of the colonial myth in postcolonial development through modeling such feedback processes across a range of colonial contexts. In Veracruz, that positive-feedback loop operated through depopulation due to epidemics, old-field succession, land dispossession through recategorization as wasteland, and consequent further depopulation, old-field succession, and land dispossession. That a similar feedback process might have operated in other regions of the Americas, such as New England (Cronon 1983; Denevan 1992a), suggests the possibility of modeling the emergence of the myth of emptiness for a range of types of colonialism. Hulme's (1992) heuristic "colonial triangle" - with "European," "native," and "land" at the apexes-provides a way of classifying types of colonialism on the basis of interactions among colonizers, colonized, and environment in order to understand the range of material-conceptual transformations involved in dispossessing natives 
of their lands through facilitating classification on the basis of cultural and environmental variables. In terms of political ecology, for example, settler and franchise colonization would each have entailed distinct interactions among colonizer, colonized, and environment. Settler colonization is associated with a landscape transformation that removes the colonized and accumulates space for the colonizer, while franchise colonization is associated with a landscape transformation that exploits native or transported labor (Wolf 1982). Settler and franchise colonization thus emerge through distinct, material-conceptual transformations; in terms of racial categorizations in relation to land and labor, for example, Australian Aborigines, although as dark-skinned as African Americans, impeded space accumulation rather than laboring on plantations and, thus, suffered the same categorization as the natives of the U.S. and Canada: a "dying race with a naturally weak constitution" rather than a "fecund race endowed with a primal virility and sense of rhythm" (Wolfe 1997). In terms of cultural ecology, long isolation from the major regions of animal domestication distinguishes the Americas in terms of susceptibility to epidemic diseases (Crosby 1972), while the climatic parameters for biotic dispersals partially distinguish temperate and tropical colonialisms (Crosby 1986). The period of colonization (de Souza 1986) — affecting technological, conceptual, and most other parameters-suggests a further basis for classifying types of colonialism in order to model the emergence of and thereby unmake the myth of emptiness at the global scale.

More systematic study of variation in positivefeedback processes, which the Veracruz case confirms were essential to simultaneously transform landscapes and obscure such transformation, necessitates modifying Hulme's colonial triangle by replacing "land" with "landscape." That modification emphasizes the spatial dimension of colonialism and the need to explicitly model changes in the patterning of population, vegetation, land use, and land-use categories as integral to rather than mere manifestations of transformative processes. In Veracruz, for example, recognizing the progressive fragmentation and old-field succession of agricultural patches in a matrix of moribund cultural savanna that itself visually ratified the Spaniards' land-use categories is essential to understanding how space accumulation proceeded despite legislative parameters genuinely intended to protect native communities and, far from incidentally, the Crown's tax base. In contrast, a focus on deconstructing texts and other representations of landscapes to the exclusion of investigating transformations of the represented landscapes themselves (Mallon 1994; WillemsBraun 1997) restricts analysis to the conceptual and precludes any understanding of the emergence of those representations through spatial, material-conceptual feedback processes. Moreover, forsaking direct investigation of material landscapes themselves precludes understanding of precolonial concepts and practices that go unrepresented except as relict landscape morphologies, for example, the recent indications of precolonial agricultural fields in British Columbia (Deur 1997). After all, the colonization of the Americas did not proceed through the unilateral imposition of the colonizers' visions, such as Cortés's representation of the Veracruz lowlands, but through transformative processes in which landscape patterning influenced both the habits of thought as well as practice that lend regularity to such processes as well as the conflicts that disturb that regularity. If the project is to understand how Western landscape categories became the be-all and end-all measures of productive land uses, and thereby learn how to appreciate alternative, perhaps more sustainable landscapes, we had best engage in integrated studies of real landscapes and their equally real representations.

\section{Acknowledgments}

My thanks to several colleagues who commented on this paper, providing many insights that helped to sharpen logic and prose: William M. Denevan, R. Cole Harris, Adam Rome, Alfred H. Siemens, B. L. Turner II, L. Yapa, and several anonymous reviewers. A preliminary version was presented at the 1998 meeting of the Association of American Geographers in Boston.

\section{Notes}

1. From an interview with Miguel Ángel Asturias (quoted in Harss and Dohmann 1993:429), author of the 1949 seminal work in the Magic Realism genre: Hombres de Maíz [Men of Maize] (Asturias 1993).

2. This first of five cartas de relación, dispatches from Cortés to Charles V spanning the years 1519_ 1526, was signed by "La Justicia y Regimiento de La Rica Villa de La Vera Cruz" on 10 July 1519 , but Cortés clearly wrote or dictated the dispatch. Chalchicueyecan is now the city and port of 
Veracruz, its location having shifted several times during the sixteenth century (Sluyter 1996). In 1519, the Spaniards first founded La Villa Rica de la Vera Cruz at Chalchicueyecan, the mainland opposite San Juan de Ulúa. They then refounded and built the town fifty-eight kilometers to the north, at present-day Villa Rica. Ca. 1525, the Spaniards dropped La Villa Rica from the toponym and moved the port to the left bank of the Río de la Antigua, at present-day La Antigua; launches ferried goods from the deep-water port at San Juan de Ulúa along the coast and across the bar at the river's mouth to Vera Cruz. Beginning with a viceregal order of 1597 and progressing over a transitional period of several years, Vera Cruz shifted back to its first location at Chalchicueyecan, and the toponym eventually became Veracruz.

3. The league in question, the legua legal, equals 4.2 kilometers (2.6 miles). The 1580 relación geográfica, a standardized geographical report, is in the Joaquin García Icazbalceta Collection of the University of Texas at Austin, cited as JGI.

4. Much fuller treatment of methodological issues and citations for all pertinent land grants can be found elsewhere (Sluyter 1997a, 1998).

5. The following grants contain the vegetation data summarized in Figure 5: Mexico City, Archivo General de la Nación, Mercedes Section (hereafter, AGN-M), vol. 6, ff. 199r-199v, 207v-208r; vol. 8, ff. 190r-190v; vol. 9, ff. 5r-5v, 30v-31r, $33 \mathrm{r}-33 \mathrm{v}, 108 \mathrm{v}-109 \mathrm{r}, 115 \mathrm{v}-116 \mathrm{r}$; vol. 10, ff. $45 \mathrm{v}-46 \mathrm{r}, 61 \mathrm{r}-61 \mathrm{v}, 65 \mathrm{v}-66 \mathrm{r}, 68 \mathrm{v}-69 \mathrm{r}, 182 \mathrm{r}-182 \mathrm{v}$, 244r-245r, 266v-267r; vol. 11, ff. 38v-40r; vol. 12, ff. 5r-6r, 20v-21r, 45v-46r, 87r-87v, 96r-96v, $118 \mathrm{r}-118 \mathrm{v}$; vol. 13 , ff. $29 \mathrm{v}, 40 \mathrm{v}, 81 \mathrm{v}-82 \mathrm{r}$, $87 \mathrm{r}-87 \mathrm{v}, 113 \mathrm{r}-113 \mathrm{v}, 132 \mathrm{v}-133 \mathrm{r}$; vol. 14, ff. $80 \mathrm{v}-81 \mathrm{v}, 161 \mathrm{v}-162 \mathrm{v}, 359 \mathrm{v}-360 \mathrm{v}$; vol. 15 , ff. 25v-26v, 86r-87r, 169r-169v, 191r-192r; vol. 17, ff. $25 \mathrm{r}-25 \mathrm{v}$; vol. 19 , ff. $25 \mathrm{r}, 30 \mathrm{v}-31 \mathrm{r}, 48 \mathrm{r}-49 \mathrm{r}$, $81 \mathrm{r}-81 \mathrm{v}, 130 \mathrm{r}-131 \mathrm{r}$; vol. 20 , ff. $20 \mathrm{r}-20 \mathrm{v}$, $21 \mathrm{v}-23 \mathrm{v}, 36 \mathrm{r}-36 \mathrm{v}, 112 \mathrm{v}-113 \mathrm{r}, 114 \mathrm{r}-114 \mathrm{v}$, $117 \mathrm{r}-118 \mathrm{v}, 119 \mathrm{r}-119 \mathrm{v}, 141 \mathrm{r}-142 \mathrm{r}, 144 \mathrm{r}-145 \mathrm{r}$, 198r-199r; vol. 21, ff. 6v-8r, 47r-48v, 55r-55v, $103 \mathrm{v}-104 \mathrm{r}, 110 \mathrm{v}-111 \mathrm{r}$; vol. 25 , ff. $64 \mathrm{r}-64 \mathrm{v}$; vol. 29, ff. 128v-129r; vol. 31, ff. 192r-192v; vol. 33, ff. 112v-118v. Mexico City, Archivo General de la Nación, Tierras Section (hereafter, AGN-T), vol. 32, exp. 4; vol. 2678, exp. 12, ff. 1r-13v; vol. 2680, exp. 20, fc. 254; vol. 2688, exp. 40, f. 444; vol. 2702, exp. 12, ff. 8r-9r, 386r-397v; vol. 2702, exp. 13, ff. 398r-406v; vol. 2702, exp. 14, ff. 6r, 407r-416v; vol. 2764, exp. 15, fc. 188, fc. 193; vol. 2777, exp. 3, ff. 1r-9v; vol. 2782, exp. 16; vol. 3331, exp. 1, ff. 1r-9v.

6. The coyol espino (Acrocomia mexicana) succeeds disturbed woodlands; the coyol (Scheelea liebmannii) also thrives with disturbance, particularly periodic burning; both species yield edible fruits and thus encourage human protection (Santamaría 1992; Pennington and Sarukhan 1968).

7. Glyptodonts looked like giant armadillos.

\section{References}

Aguilar, Francisco de. 1938. Historia de la Nueva España. Mexico City: Ediciones Botas.

Altieri, M. A., ed. 1987. Agroecology: The Scientific Basis of Alternative Agriculture. Boulder, CO: Westview Press.

Anderson, Roger C. 1982. An Evolutionary Model Summarizing the Roles of Fire, Climate, and Grazing Animals in the Origin and Maintenance of Grasslands: An End Paper. In Grasses and Grasslands: Systematics and Ecology, ed. James R. Estes, Ronald J. Tyrl, and Jere N. Brunken, pp. 297-308. Norman: University of Oklahoma Press.

Arreola, Daniel D. 1980. Landscapes of NineteenthCentury Veracruz. Landscape 24:27-31.

Asturias, Miguel A. 1993. Men of Maize. Gerald Martin, ed. and trans. Pittsburgh: University of Pittsburgh Press.

Bebbington, Anthony, and Carney, Judith. 1990. Geography in the International Agricultural Research Centers: Theoretical and Practical Concerns. Annals of the Association of American Geographers 80:34-48.

Berry, Wendell. 1996. The Unsettling of America: Culture and Agriculture. San Francisco: Sierra Club Books.

Blaut, James M. 1987. Diffusionism: A Uniformitarian Critique. Annals of the Association of American Geographers 77:30-47.

- 1993. The Colonizer's Model of the World: Geographical Diffusionism and Eurocentric History. New York: Guilford Press.

Bowden, Martyn J. 1992. The Invention of American Tradition. Journal of Historical Geography 18:3-26.

Brookfield, Harold. 1975. Interdependent Development. London: Methuen.

Browder, John O., ed. 1989. Fragile Lands of Latin America: Strategies for Sustainable Development. Boulder, CO: Westview Press.

Brown, R.B. 1985. A Summary of Late-Quaternary Pollen Records from Mexico West of the Isthmus of Tehuantepec. In Pollen Records of Late-Quaternary North American Sediments, ed. V. M. Bryant Jr. and R. G. Holloway, pp. 71-93. Dallas: American Association of Stratigraphic Palynologists Foundation.

Butzer, Karl W. 1988. Cattle and Sheep from Old to New Spain: Historical Antecedents. Annals of the Association of American Geographers 78:29-56.

- 1992. Judgment or Understanding?: Reflections on 1492. Queen's Quarterly 99:581-600.

Chapin, Mac. 1988. The Seduction of Models: Chinampa Agriculture in Mexico. Grassroots Development 12:8-17. 
Cházaro Basáñez, Miguel de J. 1977. El Huizache, Acacia pennatula (Schlech. \& Cham.) Benth.: Una Invasora del Centro de Veracruz. Biótica 2(3):1-18.

Clay, Jason W. 1988. Indigenous Peoples and Tropical Forests: Models of Land Use and Management from Latin America. Cambridge, MA: Cultural Survival.

Cockcroft, James D. 1990. Mexico: Class Formation, Capital Accumulation, and the State. New York: Monthly Review Press.

Cook, Sherburne F, and Simpson, Lesley B. 1948. The Population of Central Mexico in the Sixteenth Century. Ibero-Americana 31. Berkeley: University of California Press.

Corominas, Joan. 1973. Breve Diccionario Etimológico de la Lengua Castellana. Madrid: Gredos.

Cortés, Hernán. 1988. Cartas de Relación. Mexico City: Editorial Porrúa.

Cosgrove, Denis. 1993. The Palladian Landscape: Geographical Change and Its Cultural Representations in Sixteenth-Century Italy. University Park: Pennsylvania State University Press.

Cowell, C. Mark. 1995. Presettlement Piedmont Forests: Patterns of Composition and Disturbance in Central Georgia. Annals of the Association of American Geographers 85:65-83.

Cronon, William. 1983. Changes in the Land: Indians, Colonists and the Ecology of New England. New York: Hill and Wang.

Crosby, Alfred W. 1972. The Columbian Exchange: Biological and Cultural Consequences of 1492. Westport, CT: Greenwood Press.

- 1986. Ecological Imperialism: The Biological Expansion of Europe, 900-1900. Cambridge: Cambridge University Press.

Daneels, Annick. 1992. Patrón de Asentamiento Prehispánico en la Cuenca de Veracruz, México. In Consejo de Arqueología, Boletín, 1991, pp. 71-74. Mexico City: Instituto Nacional de Antropología e Historia.

de Souza, Anthony R. 1986. To Have and Have Not: Colonialism and Core Periphery Relations. Focus 36(3):14-19.

Denevan, William M. 1992a. The Pristine Myth: The Landscape of the Americas in 1492. Annals of the Association of American Geographers 82:369-85.

_ ed. 1992b. The Native Population of the Americas in 1492. Madison: University of Wisconsin Press.

. 1996. Carl Sauer and Native American Population Size. Geographical Review 86:385-97.

Deur, Douglas. 1997. Was the Northwest Coast Agricultural?: Ecological, Archaeological, and Ethnographic Evidence. Paper presented at the Annual Meeting of the American Association for the Advancement of Science, Seattle, WA, February 15 .

Doolittle, William E. 1992. Agriculture in North America on the Eve of Contact: A Reassessment.
Annals of the Association of American Geographers 82:386-401.

Driever, Steven L. 1995. The Veracruz-Mexico City Routes in the Sixteenth Century and the Study of Pre-Industrial Transport in Historical Geography. Geografía y Desarrollo 12 (September): 5-18.

Duncan, James S. 1990. The City as Text: The Politics of Landscape Interpretation in the Kandyan Kingdom. Cambridge: Cambridge University Press.

Fairhead, James, and Leach, Melissa. 1995. False Forest History, Complicit Social Analysis: Rethinking Some West African Environmental Narratives. World Development 23:1023-35.

García, Enriqueta. 1970. Los Climas del Estado de Veracruz. Anales del Instituto de Biología, Serie Botánica 41:3-42.

García Payón, José. 1971. Archaeology of Central Veracruz. In Handbook of Middle American Indians, vol. 11, Archaeology of Northern Mesoamerica, ed. Gordon F. Ekholm and Ignacio Bernal, pp. 505-42. Austin: University of Texas Press.

Glacken, Clarence J. 1967. Traces on the Rhodian Shore: Nature and Culture in Western Thought from Ancient Times to the End of the Eighteenth Century. Berkeley: University of California Press.

Gliessman, S. R., ed. 1990. Agroecology: Researching the Ecological Basis for Sustainable Agriculture. New York: Springer-Verlag.

Gómez-Pompa, Arturo. 1973. Ecology of the Vegetation of Veracruz. In Vegetation and Vegetational History of Northern Latin America, ed. Alan Graham, pp. 73-148. Amsterdam: Elsevier.

—- Morales, Hector Luis; Jiménez Avilla, Epifanio; and Jiménez Avilla, Julio. 1982. Experiences in Traditional Hydraulic Agriculture. In Maya Subsistence: Studies in Memory of Dennis E. Puleston, ed. Kent V. Flannery, pp. 327-42. New York: Academic Press.

Harley, J. Brian. 1992. Rereading the Maps of the Columbian Encounter. Annals of the Association of American Geographers 82:522-42.

Harris, David R. 1966. Recent Plant Invasions in the Arid and Semi-Arid Southwest of the United States. Annals of the Association of American Geographers 56:408-22.

Harris, R. Cole. 1994. Voices of Disaster: Smallpox around the Strait of Georgia in 1782. Ethnohistory 41:591-626.

Harss, Luis, and Dohmann, Barbara. 1993. Miguel Ángel Asturias, or the Land Where the Flowers Bloom. In Men of Maize, ed. and trans. Gerald Martin, pp. 413-33. Pittsburgh: University of Pittsburgh Press.

Hecht, Susanna B., and Cockburn, Alexander. 1989. The Fate of the Forest: Developers, Destroyers and Defenders of the Amazon. London: Verso.

Henige, David. 1998. Numbers from Nowhere: The American Indian Contact Population Debate. Norman: University of Oklahoma Press. 
Hulme, Peter. 1992. Colonial Encounters: Europe and the Native Caribbean, 1492-1797. New York: Routledge.

Instituto Nacional de Estadística, Geografía e Informática (INEGI). 1981. Carta Edafológica, México and Villahermosa sheets. Thematic map, 1:1,000,000. Mexico City: INEGI.

- 1984. Carta Uso del Suelo y Vegetación, sheets E14-3, E14-6, and E15-1-4. Thematic map, 1:250,000. Mexico City: INEGI.

Jackson, Wes. 1994. Becoming Native to This Place. Lexington: University Press of Kentucky.

Janzen, Daniel H., and Martin, Paul S. 1982. Neotropical Anachronisms: The Fruits the Gophotheres Ate. Science 215:19-27.

Jennings, Bruce H. 1988. Foundations of International Agricultural Research: Science and Politics in Mexican Agriculture. Boulder, CO: Westview Press.

Las Casas, Bartolomé de. 1951. Historia de las Indias, 3 vols. Mexico City: Fondo de Cultura Económica.

- 1967. Apologética Historia Sumaria, 2 vols. Mexico City: Universidad Nacional Autónoma de México.

Latour, Bruno. 1993. We Have Never Been Modern. Cambridge, MA: Harvard University Press.

Lauer, Wilhelm. 1978. Okologische Klimatypen am Ostabfall der Mexikanischen Meseta. Erdkunde 32:101-10.

Lockhart, James, and Otte, Enrique. 1976. Letters and People of the Spanish Indies, Sixteenth Century. Cambridge: Cambridge University Press.

Lowe, Lisa. 1991. Critical Terrains: French and British Orientalisms. Ithaca, NY: Cornell University Press.

Lowenthal, David. 1976. The Place of the Past in the American Landscape. In Geographies of the Mind: Essays in Historical Geosophy in Honor of John Kirtland Wright, ed. David Lowenthal and Martyn J. Bowden, pp. 89-117. New York: Oxford University Press.

_ and Bowden, Martyn J., eds. 1976. Geographies of the Mind: Essays in Historical Geosophy in Honor of John Kirtland Wright. New York: Oxford University Press.

MacCleery, D. 1994. Understanding the Role the Human Dimension Has Played in Shaping America's Forest and Grassland Landscapes: Is There a Landscape Archaeologist in the House? EcoWatch 2/10/94: http://www.fs.fed.us/eco/ecowatch/ew940210.htm (accessed on 9 June 1998).

Mallon, Florencia E. 1994. The Promise and Dilemma of Subaltern Studies: Perspectives from Latin American History. American Historical Review 99:1491-1515.

Martir de Angleria, Pedro. 1964. Decadas del Nuevo Mundo, 2 vols. Mexico City: Porrúa.

Mason, Charles T., and Mason, Patricia B. 1987. A Handbook of Mexican Roadside Flora. Tucson: University of Arizona Press.

Melville, Elinor G. K. 1990. Environmental and Social Change in the Valle de Mezquital, Mexico,
1521-1600. Comparative Studies in Society and History 32:24-53.

- 1994. A Plague of Sheep: Environmental Consequences of the Conquest of Mexico. Cambridge: Cambridge University Press.

Mitchell, Don. 1996. The Lie of the Land: Migrant Workers and the California Landscape. Minneapolis: University of Minnesota Press.

Mota y Escobar, Alonso de la. 1939-1940. Memoriales del Obispo de Tlaxcala. Anales del Instituto Nacional de Antropología e Historia 1:191-306.

Muir, John. 1894. The Mountains of California. New York: Century Co.

Netting, Robert McC. 1993. Smallholders, Householders: Farm Families and Ecology of Intensive, Sustainable Agriculture. Stanford, CA: Stanford University Press.

Niembro Rocas, Aníbal. 1986. Arboles y Arbustos Utiles de México. Mexico City: Limusa.

O’Gorman, Edmundo. 1958. La Invención de América: El Universalismo de la Cultura de Occidente. Mexico: Fundo de Cultura Económica.

O'Hara, Sarah L. 1995. Review of A Plague of Sheep: Environmental Consequences of the Conquest of Mexico, by Elinor G. K. Melville. Mountain Research and Development 15:359-61.

Parsons, James J. 1996. "Mr. Sauer" and the Writers. The Geographical Review 86:22-41.

Paso y Troncoso, Francisco del, ed. 1905. Papeles de Nueva España, 9 vols. Madríd: Sucesores de Rivadeneyra.

Peacock, Evan. 1998. Historical and Applied Perspectives on Prehistoric Land Use in Eastern North America. Environment and History 4:1-29.

Peet, Richard, and Watts, Michael. 1993. Development Theory and Environment in an Age of Market Triumphalism. Economic Geography 69:227-53

Pennington, T.D., and Sarukhan, José. 1968. Manual para la Identificación de Campo de los Principales Arboles Tropicales de México. Mexico City: Instituto Nacional de Investigaciones Forestales and Organización de las Naciones Unidas para la Agricultura y la Alimentación.

Pickett, S.T.A., and Cadenasso, M.L. 1995. Landscape Ecology: Spatial Heterogeneity in Ecological Systems. Science 269:331-34.

Pohl, Mary D.; Pope, Kevin O.; Jones, John G.; Jacob, John S.; Piperno, Dolores R.; deFrance, Susan D.; Lentz, David L.; Gifford, John A.; Danforth, Marie E.; and Josserand, J. Kathryn. 1996. Early Agriculture in the Maya Lowlands. Latin American Antiquity 7:355-72.

Pozas, Ricardo, and H. de Pozas, Isabel. 1971. Los Indios en las Clases Sociales de México. Mexico City: Siglo XXI.

Recopilación. 1987. Recopilación de Leyes de los Reynos de las Indias, 5 vols. Mexico City: Porrúa.

Rzedowski, J. 1983. Vegetación de México. Mexico City: Limusa. 
Said, Edward W. 1979. Orientalism. New York: Vintage Books.

- 1993. Culture and Imperialism. New York: Alfred A. Knopf.

Sanders, William T. 1992. The Population of the Central Mexican Symbiotic Region, the Basin of Mexico, and the Teotihuacán Valley in the Sixteenth Century. In The Native Population of the Americas in 1492, ed. William M. Denevan, pp. 85-150. Madison: University of Wisconsin Press.

Santamaría, Francisco J. 1992. Diccionario de Mejicanismos. Mexico City: Porrúa.

Sartorius, Carl. 1961. Mexico about 1850. Stuttgart: F.A. Brockhaus.

Sauer, Carl O. 1935. Aboriginal Population of Northwestern Mexico. Ibero-Americana 10. Berkeley: University of California Press.

- 1950. Grassland Climax, Fire, and Man. Journal of Range Management 3:16-21.

— 1956. Summary Remarks: Retrospect. In Man's Role in Changing the Face of the Earth, 2 vols., ed. William L. Thomas, vol. 2, pp. 1131-35. Chicago: University of Chicago Press.

.1958. Man in the Ecology of Tropical America. Proceedings of the Ninth Pacific Science Congress, 1957 20:105-10.

- 1966. The Early Spanish Main. Berkeley: University of California Press.

Schama, Simon. 1995. Landscape and Memory. New York: Alfred A. Knopf.

Siemens, Alfred H. 1983. Oriented Raised Fields in Central Veracruz. American Antiquity 48:85-102.

-1990a. Between the Summit and the Sea: Central Veracruz in the Nineteenth Century. Vancouver: University of British Columbia Press.

. 1990b. Reducing the Risk: Some Indications Regarding Pre-Hispanic Wetland Agricultural Intensification from Contemporary Use of a Wetland/Terra Firma Boundary Zone in Central Veracruz. In Agroecology: Researching the Ecological Basis for Sustainable Agriculture, ed. S.R. Gliessman, pp. 233-50. New York: Springer-Verlag.

- 1998. A Favored Place: San Juan River Wetlands, Central Veracruz, A.D. 500 to the Present. Austin: University of Texas Press.

-; Hebda, Richard J.; Navarrete Hernández, Mario; Piperno, Dolores R.; Stein, Julie K.; and Zolá Báez, M. G. 1988. Evidence for a Cultivar and a Chronology from Patterned Wetlands in Central Veracruz, Mexico. Science 242:105-07.

Simpson, Lesley Byrd. 1952. Exploitation of Land in Central Mexico in the Sixteenth Century. IberoAmericana 36. Berkeley: University of California Press.

Skerritt Gardner, David. 1989. Una Historia Agraria en el Centro de Veracruz, 1850-1940. Jalapa: Universidad Veracruzana, Centro de Investigaciones Históricas.

Sluyter, Andrew. 1994. Intensive Wetland Agriculture in Mesoamerica: Space, Time, and Form. Annals of the Association of American Geographers 84:557-84.

- 1996. The Ecological Origins and Consequences of Cattle Ranching in Sixteenth-Century New Spain. The Geographical Review 8:161-77.

- 1997a. Archival Research on Livestock and Landscape Change in Sixteenth-Century Mexico. Conference of Latin Americanist Geographers Yearbook 23:27-39.

- 1997b. On Excavating and Burying Epistemologies. Annals of the Association of American Geographers 87:700-02.

- 1997c. Regional, Holocene Records of the Human Dimension of Global Change: Sea-Level and Land-Use Change in Prehistoric Mexico. Global and Planetary Change 14:127-46.

- 1998. From Archive to Map to Pastoral Landscape: A Spatial Perspective on the Livestock Ecology of Sixteenth-Century New Spain. Environmental History 3: 508-29.

Sluyter, Andrew, and Siemens, Alfred H. 1992. Vestiges of Prehispanic, Sloping-Field Terraces on the Piedmont of Central Veracruz, Mexico. Latin American Antiquity 3:148-60.

_ 1998. A Cultural-Ecological Model of Long-Term Landscape Transformation for the Allegheny $\mathrm{Na}$ tional Forest. Paper presented at the 69th Annual Meeting of the Society for Pennsylvania Archaeology, New Cumberland, PA, April 24-26.

Stevens, Rayfred L. 1967. European Settlement Ventures in the Tropical Lowlands of Mexico. Erdkunde 21:258-77.

Todorov, Tzvetan. 1984. The Conquest of America: The Question of the Other. New York: Harper and Row.

Torquemada, Juan de. 1969. Monarquía Indiana, 3 vols. Mexico City: Editorial Porrúa.

Turner, B. L. II, and Butzer, Karl W. 1992. The Columbian Encounter and Land-Use Change. Environment 34(8): 16-20, 37-44.

—_ Clark, William C.; Kates, Robert W.; Richards, John F; Mathews, Jessica T.; and Meyer, William B., eds. 1990. The Earth as Transformed by Human Action: Global and Regional Changes in the Biosphere over the Past 300 Years. Cambridge: Cambridge University Press.

von Humboldt, Alexander. 1811[1966]. Political Essay on the Kingdom of New Spain, 4 vols. New York: AMS Press.

von Mentz, Brígida. 1990. Estudio Preliminar. In México Hacia 1850, ed. and trans. Brígida von Mentz, pp. 11-45. Mexico: Consejo Nacional para la Cultura y las Artes.

Wallerstein, Immanuel. 1974. The Modern World-System: Capitalist Agriculture and the Origins of the European World-Economy in the Sixteenth Century. New York: Academic Press.

White, R. 1984. Native Americans and the Environment. In Scholars and the Indian Experience: Critical Reviews of Recent Writing in the Social Sciences, 
ed. W. R. Swagerty, pp. 179-204. Bloomington: Indiana University Press.

Whitmore, Thomas M., and Turner, B.L. II. 1992. Landscapes of Cultivation in Mesoamerica on the Eve of the Conquest. Annals of the Association of American Geographers 85:541-56.

Wilbanks, Thomas J. 1994. "Sustainable Development" in Geographic Perspective. Annals of the Association of American Geographers 84:541-56.

Wilken, Gene C. 1987. Good Farmers: Traditional Agricultural Resource Management in Mexico and Central America. Berkeley: University of California Press.

Willems-Braun, Bruce. 1997. Buried Epistemologies: The Politics of Nature in (Post)colonial British Columbia. Annals of the Association of American Geographers 87:3-31.

Wolf, Eric R. 1982. Europe and the People without History. Berkeley: University of California Press.
Wolfe, Patrick. 1997. History and Imperialism: A Century of Theory, from Marx to Postcolonialism. American Historical Review 102:388-420.

Wright, John K. 1947. Terrae Incognitae: The Place of the Imagination in Geography. Annals of the Association of American Geographers 37:1-15.

Yapa, Lakshman. 1993. What Are Improved Seeds? An Epistemology of the Green Revolution. Economic Geography 69:254-73.

Zea, Leopoldo. 1975. El Positivismo en México: Nacimiento, Apogeo y Decadencia. Mexico City: Fondo de Cultura Económica.

Zimmerer, Karl S. 1994. Human Geography and the "New Ecology": The Prospect and Promise of Integration. Annals of the Association of American Geographers 84:108-25.

- 1996. Changing Fortunes: Biodiversity and Peasant Livelihood in the Peruvian Andes. Berkeley: University of California Press.

Correspondence: Department of Geography, The Pennsylvania State University, University Park, PA 16802, email sluyter@gis.psu.edu. 